\title{
China and the Chinese Rites Controversy in Dutch Newspapers
}

In the last quarter of the seventeenth century, developments in both Europe and China changed the manner in which the Middle Kingdom was represented to Dutch readers. ${ }^{1}$ This chapter explores how newspapers and periodicals printed in the Dutch Republic during the final decades of the seventeenth century reported and discussed Confucius and the so-called Chinese Rites Controversy. In this regard, this chapter examines how changes in the Jesuit mission, combined with developments in production, distribution, and availability of printed media, produced an image of China and its religion and philosophy that was increasingly focused on the Chinese Rites Controversy and the condemnation of the Jesuit missionary approach. Furthermore, over the course of the seventeenth century, Dutch-made news became influenced more and more by French culture and language. These shifts impacted representations of China and Confucius, whereby Dutch printers, publishers, and booksellers produced and distributed a progressively Gallican image of the Middle Kingdom.

The early modern culture of news has received considerable attention in recent years. Scholars like Brendan Dooley, Joad Raymond, Joop Koopman, and Paul Arblaster have all advocated an interpretation of news that focuses primarily on production and distribution. ${ }^{2}$ Their attention has concentrated on the emergence of the periodic press and the distribution of news through international networks of book producers, translators, merchants, missionaries, diplomats, and religious immigrants. Research in this field has also investigated the relationship between news and public opinion. For example, an approach towards news culture as part of the early modern book market has

1 Parts of this chapter first appeared in 'It is said that ... The Chinese Rites Controversy in Dutch newspapers and periodicals in the seventeenth century', Jaarboek voor Nederlandse boekgeschiedenis, 23 (2016), pp. 172-191.

2 Paul Arblaster, From Ghent to Aix. How they brought the news in the Habsburg Netherlands, 1550-1700 (Leiden: Brill, 2014); Brendan Dooley (ed.), The dissemination of news and the emergence of contemporaneity in early modern Europe (Farnham: Ashgate, 2010); Joop Koopmans, News and politics in early modern Europe (1500-1800) (Leuven: Peeters, 2005); Joad Raymond and Noah Moxham (eds.), News networks in seventeenth-century Britain and Europe (Abingdon: Routledge, 2006). 
been taken up by Andrew Pettegree and Arthur Der Weduwen. ${ }^{3}$ Additionally, recent studies by Michiel van Groesen, Helmer Helmers and others have further proposed to merge the various historiographies of news and information management by integrating these fields of study with Robert Darnton's circuit of communication. ${ }^{4}$ Following an integrated approach towards these methodologies, this chapter seeks to examine the role of printers, publishers, and authors in shaping the early modern representations of China in newspapers.

Reports in early modern Dutch newspapers often concerned the nonEuropean world. These reports were significant in that they changed the manner in which readers could relate to the Americas, Africa, Asia, and Australia by providing (relatively) current information which hitherto had only been available to a small part of society. By employing the periodic press, Michiel van Groesen has demonstrated that Dutch Brazil transformed (and was transformed by) the media landscape in the Dutch Republic. ${ }^{5}$ With one notable exception, little research has been done on the representation of China in the European periodic press of the seventeenth century. Edwin van Kley's ground-breaking work, 'News from China', has shown that news about the Manchu conquest of 1644 had remarkable effects on Europe; the conquest was deemed incredibly important and was subjected to a wide variety of interpretations in the periodic press. Before 1644, however, reports about China were primarily static affairs as opposed to histories or news. In the words of Van Kley: 'The image of China produced by such flat descriptions was flat; it lacked both a historical dimension in the background and individual personalities or discrete events in the foreground. ${ }^{6}$ However, the conquest changed the nature of news on the Middle Kingdom by dramatizing the events and allowing for more substantial debates over the significance of Chinese incidents.

3 Andrew Pettegree, The book in the Renaissance (New Haven: Yale University Press, 2010); Andrew. Pettegree, The invention of news. How the world came to know about itself (New Haven: Yale University Press, 2014); Arthur der Weduwen, Dutch and Flemish newspapers of the seventeenth century, 1618-1700 (2 vol., Leiden: Brill, 2017); Arthur der Weduwen, "Everyone has hereby been warned." The structure and typography of broadsheet ordinances and the communication of governance in the early seventeenth-century Dutch Republic', in Andrew Pettegree (ed.), Broadsheets. Single-sheet publishing in the first age of print (Leiden: Brill, 2017), pp. 240-267; Pettegree and Der Weduwen, The bookshop of the world.

4 Michiel van Groesen and Helmer Helmers, 'Managing the news in early modern Europe, 1550-18oo', Media History, 22.3-4 (2016), pp. 261-266.

5 Michiel van Groesen, Amsterdam's Atlantic. Print culture and the making of Dutch Brazil (Philadelphia: University of Pennsylvania Press, 2017).

6 Van Kley, 'News from China', p. 562 . 
News from China retained this dynamic quality in the following decades. Jesuit missionaries and merchants from various trading companies provided generally accurate accounts, and the emerging news culture encouraged discussion on a more extensive and influential level. Europe thus became increasingly familiar with China and her recent history. In the second half of the seventeenth century, an enormous amount of information about the Middle Kingdom reached the (Dutch) printing presses, which, as we have seen in previous chapters, became popular and widely read. Furthermore, when the Chinese Rites Controversy became a publicly discussed issue during the $168 \mathrm{os}$ and 169 os, this information acquired even greater immediacy and dynamism. China truly became part of the European conscience, a development that was aided by printed works produced in the Dutch Republic.

This chapter aims to explain how a primarily Catholic debate, which mainly concerned France and Rome, was presented to a European public in periodicals produced by Dutch printers and publishers. It further explores how production and textual transmission influenced the possible representations of China, the Chinese Rites Controversy, and the Society of Jesus. Reports in Dutch-made newspapers may be considered either the critical commentary of one text on another text, or more passing or casual allusion, depending on the strategy of the publisher. These relationships between different texts on the Middle Kingdom are used to trace how newspapers often reported the same event, but in decisively different manners. Significantly, such a focus demonstrates how early modern images of China in print went beyond merely informing readers about events happening in a country far away. News about China was influenced by a variety of factors including its source, the strategy of the publisher and editor, and the presumed wishes of the potential readership.

This chapter focuses on news in the Dutch Republic and provides a general reflection on the unique character of Dutch newspapers and news digests. Dutch printers and publishers provided the whole of Europe with printed works that reported on recent events in Dutch and various other languages. Especially the papers in French, the so-called Gazettes de Hollande, were highly influential. These newspapers existed alongside their Dutch counterparts, but had a different readership; therefore, their approach towards China, the Chinese Rites Controversy, and the Society of Jesus was a divergent one. For further insights into the nature of Dutch-made print, books and pamphlets written by French Jesuit missionaries published in the Dutch Republic are discussed. During the final quarter of the seventeenth century, a Jesuit mission sent by Louis XIV played an increasingly important role in the formation of European images of China. This mission is vital to understanding not only how 
the printed medium became 'French', but also how the knowledge distributed began to focus on French sources, subjects, and interests. ${ }^{7}$

A considerable amount of Dutch-made news on China was printed in French. Nonetheless, the Dutch Republic certainly saw the publication of many news items about the Middle Kingdom in Dutch. This chapter examines the nature of these notices: their content, intended public, and their representation of China. As this section reveals, Dutch-language news was mostly concerned with events that could have an economic, political, or military impact on the activities of the Dutch in Asia. Consequently, these papers only sporadically reported on the Chinese Rites Controversy or the Jesuits. China is still mentioned often, however, but in the form of advertisements as Chinese items were offered for sale by numerous merchants.

This chapter analyses French-language news published in the Dutch Republic. The censorship of Louis Le Comte's account of China by the Sorbonne (1700) shows how newspapers printed in the Dutch Republic often gave different accounts of the same event. Papers in French focused more on the presumed Catholic interests of their readers and consequently were often rather outspoken in their anti-Jesuit condemnation of Le Comte and the Chinese rites. This chapter further examines the various pamphlets that were published during the height of the Chinese Rites Controversy around 1700. These debates hardly concerned the Dutch, yet were furtively printed in Holland. Surprisingly, most of these pamphlets bear a fictitious imprint from Cologne and, as such, may offer clues to the changing role of the Dutch Republic in the provision of news on China at the turn of the eighteenth century. The last section concerns the discussion of China and the Rites Controversy in news digests. These so-called Mercuren summarised and ordered the news of recent months. Compared to newspapers, topics were presented in a more integrated manner. Hence, these digests provided a more comprehensive (and therefore different) discussion of China.

By considering these media, it becomes evident that even the publications that, at first glance, seemed to owe little to the Dutch, were largely indebted to the unique print culture of the United Provinces. Compared to other countries in Europe, the Dutch had fewer hesitations about openly discussing political or religious issues, and almost any major event was accompanied by a large number of pamphlets. ${ }^{8}$ The Chinese Rites Controversy was primarily a French

7 Brockey, Journey to the East, pp. 126-163; Rui Magone, 'Portugal and the Jesuit mission to China. Trends in historiography', History of Mathematical Sciences (2012), pp. 3-20.

8 Craig Harline, Pamphlets, printing, and political culture in the early Dutch Republic (Dordrecht: Nijhoff, 1987), p. 3 . 
and Catholic debate, yet publishers in the Dutch Republic had few qualms and much to gain by joining the fray.

\section{$1 \quad$ Publishing News in the Dutch Republic}

Besides being the European nucleus for the production of books and journals, Amsterdam and the Dutch Republic were an important centre for the production and distribution of news. The origin of the periodic news sheet, however, can be traced to the Venetian Republic of the sixteenth century. There, an early form of handwritten newspaper called avissi or gazettes circulated as a single, folded sheet that appeared on a regular (often weekly) schedule. Their main function was to circulate news, especially political, military, or economic tidings, quickly and efficiently. ${ }^{9}$ Soon, the periodic news sheet found its way from Italy to Germany and Holland. Newspapers came to the Dutch Republic in 1618, appearing first in Amsterdam. ${ }^{10}$ By 1645 , this city alone boasted seven different titles by six publishers, who issued ten weekly editions on four days of the week. ${ }^{11}$ Outside Amsterdam, newspapers appeared in Arnhem (1619), Delft (1620), The Hague (1652), Haarlem (1656), Weesp (1656), Utrecht (1658), Rotterdam (1666), and Leiden (1686). ${ }^{12}$

The newspaper output of the Dutch Republic is all the more striking when compared to their publication elsewhere in Europe. In France and the Holy Roman Empire, a smaller number of periodicals served a greater number of readers. ${ }^{13}$ Printed news came to Italy in the $1630 s$, while the first newspaper of Spain was published in $1661 .{ }^{14}$ Britain's first daily newspapers were launched in

9 Filippo DeVivo, 'Paolo Sarpi and the uses of information in seventeenth-century Venice', Media History, 11.1 (2005), pp. 37-51; Mario Infelise, 'Roman avvisi. Information and politics in the seventeenth century', in Gianvittorio Signorotto and Maria Visceglia (eds.), Court and politics in Papal Rome, 1492-1700 (Cambridge: University Press, 2002), pp. 212228; Renate Pieper, 'News from the new world. Spain's monopoly in the European network of handwritten newsletters during the sixteenth century', in Raymond and Moxham (eds.), News, pp. 495-511.

10 Folke Dahl, Dutch corantos, 1618-1650. A bibliography (The Hague: Koninklijke Bibliotheek, 1946).

11 Folke Dahl, 'Amsterdam. Earliest newspaper center of Western Europe', Het Boek, 25.3 (1939), pp. 161-198.

12 Der Weduwen, Dutch and Flemish newspapers of the Dutch Republic.

13 Frank Bösch, Mass media and historical change. Germany in international perspective, 1400 to the present (New York and Oxford: Berghahn, 2015), pp. 39-55; Kenny, The uses of curiosity in early modern France and Germany, pp. 256-277.

14 Mario Infelise, 'The war, the news and the curious. Military gazettes in Italy', in Brendan Dooley and Sabrina Alcorn Baron (eds.), The politics of information in early modern Europe 
1702, and the total production of the Spanish Netherlands never reached more than four titles at any given time. ${ }^{15}$ Thus, in the words of media historian Otto Lankhorst: 'The wealth of publications coming off the Dutch presses in the seventeenth century, which is sometimes referred to as "the Dutch miracle", certainly also included the newspaper.'16

The emergence and spread of the printing press facilitated the emergence of regular news publications. In his article on the origins of the newspaper in Europe, Johannes Weber has convincingly argued: 'At the same time, then, as the printing press in the physical, technological sense was invented, "the press" in the extended sense of the word also entered the historical stage.17 These early newspapers ushered in a new phenomenon: a system of communication that made (relatively) up-to-date information available to a socially and economically diverse public. These newspapers tied the Republic of Letters together and promoted a hitherto-unknown diffusion of knowledge. In particular, the form and regular appearance of early modern gazettes influenced the newspaper as we know it today: they were published on a folded sheet in folio size and (unlike broadsheet) generally lacked pictures and headlines. To help the reader make sense of the news, publishers quickly began to number and date each issue, as well as provide the date and place of origin of each notice they printed. Unlike books and even learned journals, newspapers were subjected to strict time constraints. Papers needed to be ready to be mailed at fixed times and printers and compositors 'frequently work as if on a forced march. While the work was more demanding than the publication of books and journals, publishers were ensured a more regular income as newspapers were often sold by subscription paid in advance.

Professional journalism only emerged during the eighteenth century; yet, even in the seventeenth century, some journalists managed to earn an income from editorial work. However, they were often dismissed as mercenaries who sold their writing skills for profit. Voltaire's article in the Encyclopédie

(London: Routledge, 2001), pp. 216-236; Henry Ettinghausen, 'Politics and the press in Spain', in Dooley and Baron, The politics of information, pp. 199-215.

15 Joad Raymond, 'Introduction. Newspapers, forgeries, and histories', in Joad Raymond (ed.) News, newspapers, and society in early modern Britain (London and Portland: Frank Cass Publishers, 1999), pp. 1-11; Otto Lankhorst, 'Newspapers in the Netherlands in the seventeenth century', in Dooley and Baron, The politics of information, pp. 151-159; Paul Arblaster, 'Policy and publishing in the Habsburg Netherlands, 1585-169o', in Dooley and Baron, The politics of information, pp. 179-198.

16 Lankhorst, 'Newspapers in the Netherlands', p. $15^{2}$.

17 Johannes Weber, 'The origins of the newspaper in Europe', German History, 24.3 (2006), pp. 387-412, p. 337 . 
complained that few journalists measured up to the standard of being 'promptly informed, truthful, impartial, simple, and correct in his style.'18 However, journalistic work was a source of income for many early modern writers and, by the end of the seventeenth century, it had become a way to establish important positions in the Republic of Letters. ${ }^{19}$

The readership of early modern Dutch-made newspapers was substantial. ${ }^{20}$ The average cost of one stuiver (2o stuivers equalled one guilder) per issue was low enough to bring them within reach of the lower middle classes, while the high literacy rate, roughly 6o per cent for men and 40 per cent for women, guaranteed the broad appeal of printed news. They were read by both professionals of the news market (merchants and statesmen) and by a wide range of literate citizens from 'middling background'. ${ }^{21}$ Newspapers were popular reading matter in reading rooms, coffee-houses, and cafés, where readers could perhaps enjoy a cup of Chinese tea with their gazette. In the newspapers, these readers found a range of reports from across Europe and the world beyond, summarising and supplementing news that was often heard elsewhere. While the actual print runs are difficult to gauge, it has been estimated that a single newspaper may have been read by as many as ten different readers, making the potential distribution of the medium indeed very large. ${ }^{22}$

Over the course of the century, publishers in the Dutch Republic accommodated weekly papers in French, English, Spanish, Italian, and Yiddish. ${ }^{23}$ Newspapers in French proved especially important. Since the Northern Netherlands had become the dominant refuge for French Huguenot exiles, the journalistic climate had changed to accommodate them and thus

18 'Gazetier', in Denis Diderot and Jean le Rond d'Alembert (eds.), Encyclopédie, ou dictionnaire raisonné des sciences, des arts et des métiers, etc., University of Chicago: ARTFL Encyclopédie Project, http://encyclopedie.uchicago.edu.

19 Jeremy D. Popkin, News and politics in the age of revolution. Jean Luzac's Gazette de Leyde, 1772-1798 (Ithaca: Cornell University Press, 1989).

20 Michiel van Groesen, 'Reading newspapers in the Dutch Golden Age', Media history, 22.3-4 (2016), pp. 334-352.

21 Der Weduwen, Dutch and Flemish newspapers, p. 5.

22 Martin Welke, 'Gemeinsame Lektüre und frühe Formen von Gruppenbildungen im 17. und 18. Jahrhundert. Zeitunglesen in Deutschland', in O. Dahn, (ed.), Lesegesellschaften und bürgerliche Emanzipation. Ein europäischer Vergleich (Munich: Beck, 1981), pp. 29-53; Michael Harris, London newspapers in the age of Walpole. A study in the origins of the modern English press (London: Associated University Presses, 1987), p. 190.

23 Hilde Pach-Oosterbroek, 'Arranging reality. The editing mechanisms of the world's first Yiddish newspaper, the Kurant (Amsterdam, 1686-1687)', PhD thesis, University of Amsterdam, 2014. 
included a sizeable French-language press. ${ }^{24}$ While Dutch-language newspapers were confined to readers who had mastered that language, the audience of French-language newspapers was more widespread, finding readers in France, the Netherlands, and throughout the whole Republic of Letters. ${ }^{25}$ Subsequently, Dutch-language newspapers were sold primarily in the Low Countries, while French-language newspapers also targeted foreign markets. Indeed, the very first newspapers of the Dutch Republic already appealed to this development; the Tijdinghen uyt verscheyde quartieren (1619-1671) and the Courante uyt Italien \& Duytschlandt (1618-1669) were translated into French as Nouvelles des divers quartiers (1639-1643) and Courant d'Italie et d'Almaigne (1620-c. 1655). ${ }^{26}$ The Gazette d'Amsterdam was the first Dutch-made journal published solely in French, issued from the second half of the seventeenth century onwards. ${ }^{27}$ More followed, of which the Gazette de Leyde (also known as Nouvelles Extraordinaires des divers endroits 1680) was the most celebrated. ${ }^{28}$

By the end of the century, Dutch publishers in five towns printed French papers: Amsterdam, The Hague, Leiden, Utrecht, and Rotterdam. ${ }^{29}$ French Huguenot refugees were usually responsible for the content, as their situation, aptitude, and needs, according to Graham Gibbs, 'ideally fitted them for the role of journalists. ${ }^{30}$ The Dutch-made gazettes de Hollande found an audience all over Europe. Demand abroad was considerable, regardless of their inflated prices and the persistent efforts by the French government to curtail the spread of news from the Dutch Republic. ${ }^{31}$ By the middle of the eighteenth century, the leading position of the gazettes was such that a newspaper entitled Observateur Hollandois was founded in Potsdam in 1744: a paper that

24 Hatin, Les gazettes de Hollande, p. 10-25.

25 Bots, De Republiek der Letteren, p. 165-197.

26 Der Weduwen, Dutch and Flemish newspapers, pp. 182; Arblaster, 'Policy and publishing', pp. 131-132.

27 It is not entirely clear in what year the Gazette d'Amsterdam was first published: sources give the dates 1663, 1668, and 1691. See Asa Briggs and Peter Burke, $A$ social history of the media. From Gutenberg to the internet (Cambridge: Polity Press, 2009), p. 59; Pierre Rétat, $L a$ Gazette d'Amsterdam, miroir de l'Europe au XVIII esiècle (Paris: Voltaire Foundation, 2001); Jeremy D. Popkin, 'The eighteenth-century French periodical press', Eighteenth-Century Studies, 37.3 (2004), pp. 483-486.

28 Hannah Barker and Simon Burrows, Press, politics and the public sphere in Europe and North America, 1760-1820 (Cambridge: Cambridge University Press, 2002), p. 170.

29 Hatin, Les gazettes de Hollande, p. 13.

$30 \quad$ Gibbs, The role of the Dutch Republic, p. 131.

31 David Pottinger, The French book trade in the ancient regime, 1500-1791 (Cambridge MA: Harvard University Press, 1958), pp. 6o-64; Pettegree, The book in the Renaissance, p. 118. 
had absolutely nothing to do with Holland, but 'attempted to invest Prussian journalism with something of the reflected glory of Dutch journalism.' ${ }^{32}$ French-language newspapers catered to the international Republic of Letters and, more generally, to the growing number of European readers literate in French. Latin remained the language of scholarship and education, but the opportunities to learn, read, speak, and write French increased over the course of the century. This development was stimulated by the presence in the Dutch Republic of Walloon communities that acted as centres of French culture. ${ }^{33}$

Readers could also get their news from the so-called Mercuren (named after the Classical winged messenger Mercury). Examples are the Hollandse mercurius (1650-169o), the Europische mercurius (1690-1756), and the Mercure historique et politique (1686-1782). Their editors used national and international newspapers, making the Mercuren an excellent source into the provision of news in the Dutch Republic as well as revealing those news items that were of enduring interest. ${ }^{34}$ For instance, Joop Koopman has demonstrated that these periodicals were a separate medium with distinct characteristics, and held a contemporary significance that differed substantially from newspapers. Aside from commercial purposes, Mercuren were published for 'the coherent and regular presentation and preservation of information about important and interesting topics ... for contemporary and later generations.' ${ }^{35}$ The Mercuren also published news with explanation and commentary. Compared to newspapers, issues, such as China or the Chinese Rites Controversy, were presented in a more 'interrelated way and with more persuasive authority', and they therefore provided a distinct and comprehensive image of the Middle Kingdom and its religion and philosophy.

\section{News from China}

By the end of the seventeenth century, the newspaper had become a cultural phenomenon, as an ever-growing urban middle-class public integrated the reading of news periodicals into their social, cultural, economic, and political

32 Gibbs, The role of the Dutch Republic, p. 335 .

33 Willem Frijhoff, 'Vanishing fatherlands and moving identities. Walloons and Huguenots in the Dutch Republic', in Yosef Kaplan (ed.), Early modern ethnic and religious communities in exile (Newcastle upon Tyne: Cambridge Scholars Publishing, 2017), pp. 117-143.

34 Joop Koopmans, 'De presentatie van het nieuws in the Europische mercurius 1690-1756', Mededelingen van de Stichting Jacob Campo Weyerman, 23 (2000), pp. 117-129, p. 117.

Koopmans, 'De presentatie van het nieuws', p. 266. 
lives. ${ }^{36}$ These readers were not only provided with Dutch and European news, but also with events that happened beyond Europe. ${ }^{37}$ Van Groesen has demonstrated that news from the Atlantic world occupied a prominent place in the early modern newspaper. However, distance and opportunity made news from China less prevalent. Numerous reports on the Middle Kingdom reached the pages of the Dutch periodic press, yet there was never any consistent supply of news. This relative paucity does not mean that it has lesser value, however. The provision of news on China, however small, in Dutch newspapers confirms the degree to which the Middle Kingdom had been integrated into the main current of European culture.

In the context of this discussion, it is useful to consider what constitutes 'news'. Andrew Pettegree and Arthur der Weduwen have proposed that four requirements must be met to call any publication a newspaper. ${ }^{38}$ First, the material has to be periodic (frequent and regular); second, it has to be contemporary (new); third, the material has to be publicly available; and fourth, it has to have miscellaneous contents (reports need to come from different locations). In line with these conditions, news from China printed on Dutch presses was indeed publicly available and miscellaneous, but it was hardly every ever periodic or contemporary. As to periodicity: a round-trip from Europe to China took months, if not years, so when news from the Middle Kingdom reached the shipping ports of France, England, or the Dutch Republic it was always out of date on arrival. This is not to say that the information was not new for the recipient, it simply meant that any action required or undertaken on the basis of this information was almost certainly in vain, as the situation in Asia could have completely changed.

Consider, for instance, news about the Manchu Conquest of 1644. Edwin van Kley has shown that missives about this conquest took quite some time to reach the printing presses of Europe. Only in July 1650, six years after the event, the Hollandsche mercurius published a brief note 'confirming the calamities of the ingenious China'. ${ }^{39}$ News from the Middle Kingdom also lacked any substantial regularity. A considerable number of European ships sailed to Asia, yet

36 Der Weduwen, Dutch and Flemish newspapers, pp. 4-10.

37 Oprechte Haerlemsche courant, 6 May 1692.

38 Der Weduwen, Dutch and Flemish newspapers, pp. 5-14; Pettegree, The book in the Renaissance, pp. 130-150; E.W. Allen, 'International origins of the newspapers. The establishment of periodicity in print', Journalism \& Mass Communication Quarterly, 7.4 (1930), pp. 307-319.

39 Hollandtsche mercurius (Haarlem 1650), p. 25; Van Kley, 'News from China', p. 563. Van Kley does note that the wording of the message may imply that there had been earlier reports. 
the frequency of these travels was not reliable until the nineteenth century. ${ }^{40}$ Besides this, news was generally not acquired in China itself. Merchants often learned about Chinese events through intermediaries in Batavia. Even though this not necessarily diminished the topicality of the news, it certainly influenced the nature of the information.

Although news from China may have lacked some of the traditional characteristics of news, its increasing availability changed the manner in which European readers could relate to the country. Through coverage in the periodic press, the Middle Kingdom gained a historical dimension by showing an image of a more dynamic China. From the 165 os onwards, China was 'rather dramatically thrust into European consciousness, and Westerners began their first debate over the significance of Chinese event [s].41

This shift came as the result of the introduction of newspaper reports, which changed the way China was presented to European readers. In general, notices about Asia prior to the introduction of periodical media had been static descriptions. As Van Kley noted: 'Events that occurred in China were not reported to Europeans; Chinese government, institutions, and customs were described to Europeans. ${ }^{42}$ The distinction between reporting information and describing it is a crucial one. The representation of China in print had long been that of a remote and often idealised empire. Thanks to the influx of more detailed information, this static image was at least partially replaced with that of a more dynamic picture.

The introduction of news reports naturally increased the opportunity for debate and discussion. From the middle of the century onwards, Chinese events, such as the Manchu Conquest of 1644, provoked public speculation as to its cause and consequences. Writers began to include accounts of such events into their narratives, in which their cultural and religious background often determined how the news was presented and interpreted. For instance, the Jesuit Martino Martini presented the events of 1644 as God's punishment for the Wanli Emperor's (1572-1620) mistreatment of Christian missionaries. In contrast, Juan Palafox y Mendoza, who was embroiled in a major controversy

40 The Dutch East India Company's shipping between the Netherlands and Asia 1595-1795, Huygens-ING, via http://resources.huygens.knaw.nl/das, last accessed 24 August 2021; Hosea Ballou Morse, The chronicles of the East India Company, trading to China (Oxford: Clarendon Press, 1926); Blussé, 'No boats to China', pp. 51-76.

41 Van Kley, 'News from China', p. 562.

42 Van Kley, 'News from China', p. 562. 
with the Jesuits over ecclesiastical jurisdiction in Mexico, never even mentioned the Jesuit mission in China in relation to the conquest. ${ }^{43}$

Newspaper reports also confirm the degree to which China had been integrated into early modern Dutch culture. The periodic press, learned journals and newspapers alike, demonstrates that the Middle Kingdom became increasingly assimilated into the main currents of society during the final decades of the seventeenth century. Readers who, beforehand, may have only had a pedestrian knowledge of China, could now seek out newsworthy information in the periodic press. They did so for a variety of reasons and it becomes clear that representations of China during the last decades of the seventeenth century were as much the result of developments back home as they were the result of events in the Middle Kingdom itself.4 ${ }^{4}$

In 1942, Helen MacGill Hughes, in her study about the United States, noted that news is a relative matter and of all possible 'facts', only some can be written as news. ${ }^{45}$ She summed up the consequences of this observation by concluding that "news is whatever is news for "our" readers, and thus the news and the public that wants it are defined in terms of each other'. Interestingly, MacGill Hughes's astute comment could very well apply to the Dutch Republic in the 1640 os $^{46}$ In the seventeenth century, as today, news was a commodity. The growing presence of China in newspapers of the early modern Dutch Republic shows how the country indeed became more ingrained in the European imagination by way of the economic rules of cultural consumption. News and the demands and wishes of the public depended on each other, and newspapers provided readers with a new way of accessing Asia.

\section{Reports on China in Dutch-Made Newspapers}

By the middle of the seventeenth century, there was a distinct divergence between Dutch and French reports on China in newspapers published in the

43 Martini, De bello Tartarico; Juan de Palafox y Mendoza, Historia de la conquista de la China por el Tartaro (Paris: Antonio Bertier, 1670).

44 For a discussion of public opinion, public sphere and its role in shaping early modern news see Jürgen Habermas, Strukturwandel der Öffentlichkeit: Untersuchungen zu einer Kategorie der bürgerlichen Gesellschaft (Frankfurt am Main: Suhrkamp, 1962). A critique of this highly influential work may be found in Jan Bloemendal, Arjan van Dixhoorn, Else Strietman (eds.), Literacy cultures and public opinion in the Low Countries, 1450-1650 (Leiden: Brill, 2011). See also: Roelof Harms, Pamfletten en publieke opinie. Massamedia in de zeventiende eeuw (Amsterdam: Amsterdam University Press, 2011), p. 24.

45 Helen MacGill Hughes, 'The social interpretation of news', The Annals of the American Academy of Political and Social Science, 219 (1942), pp. 11-17.

46 MacGill Hughes, 'The social interpretation of news', p. 11. 
Dutch Republic. Dutch news primarily focused on those events that might affect the economic interests of the United Provinces, such as shipping news, the fates of Jesuit missionaries (as intermediaries between the imperial court and the Dutch), and wars and conflicts that could disrupt trading lines. The numerous advertisements for Chinese produce further emphasise the primarily economic character of Dutch news on the Middle Kingdom.

Hundreds of tidings take note of ships named China, ships going to China, ships sinking on their way to China, ships arriving from China, ships carrying Chinese products: the list is endless. ${ }^{47}$ These notes were generally brief and to the point: 'There are letters from the East Indies and from Ceylon ... that everything is well in the Indies, and that the trade with Persia and China is good' 48 Readers were often meticulously informed of the exact nature of the loads carried by ships coming from Asia. Over the course of the century, Dutch newspapers published dozens of cargo-lists, informing readers (for instance) of how in 1672 'the first ten ships from Batavia' brought with them ' 9005 pounds of China root [and] 7980 o pounds of Chinese silk'49

Although the Chinese Rites Controversy was primarily a debate that took place within the Catholic regions of Europe and therefore of lesser importance to the mainly Protestant readers of Dutch-language newspapers, this did not mean that news regarding the Jesuits in general was not reported. ${ }^{50}$ Their missionaries were an important point of contact for Dutch merchants in China; consequently, newspapers included reports on their affairs and (often) misfortunes: 'In China, there has been a dispute between Monsr. Berito and the Jesuits, who insisted on his good character. Father Adam [Schall von Bell] had died in prison, where he had been put by the king [sic] of China. ${ }^{51}$ The name of

47 These tidings were found using the online database Delpher, developed by the Royal Library in The Hague. A variety of keywords were used to search for China, or Chinese matters in newspapers printed in the Dutch Republic in the period 1 January 1640 to ${ }_{31}$ December 1720. For an overview of available titles in Delpher see www.Delpher.nl/en/ kranten\#krantenoverzicht, last accessed 24 August 2021.

48 'Daar zijn brieven uit Oost-Indie en van Ceylon ... dat het in Indie nog alles wel staat, en de handel in Perzië en mede in China goed was', in Amsterdamse courant, 20 February 1677; Pettegree, The invention of news, p. 39.

49 'De ... eerste tien schepen van Batavia ... 9005 pond radix China [en] 79800 pond of Chinese Zijde', in Amsterdamse courant, 18 August 1672.

$50 \quad$ Trude Dijkstra, 'De Oprechte Haerlemsche courant en het nieuws uit China', in Thijs Weststeijn and Menno Jonker (eds.), Barbaren en Wijsgeren. Het beeld van China in de Gouden Eeuw (Nijmegen: Vantilt, 2016), pp. 61-66.

$5^{1}$ 'In China was geschil geweest tussen de Jezuiten en Monsr. Berito, die daar zeer hard hadden gestaan op zijn karakter: de pater Adam [Schall von Bell] was overleden in de gevangenis, waar in hem de koning van China had doen zetten', in Oprechte Haerlemsche courant, 6 October 1672 . In reality, Adam Schall von Bell did not die in prison. The separate events of an earthquake in Beijing on 16 April 1665, and a palace fire on 29 April of the 
the Jesuit Schall von Bell would have been familiar to the well-informed readers for, according to Johan Nieuhof, he had wilfully sabotaged the Dutch trading embassy of $1655^{-16} 67^{52}$ Tidings on China were not just concerned with the Dutch East India Company, but also foreign trade. For instance, the Amphitrite departed out of Port-Louis in France for Guangzhou in March 1701. ${ }^{53}$ On board were the French Jesuit Jean de Fontaney and nine of his colleagues. The ship arrived at its destination on 9 September. ${ }^{54}$

Even news that was not directly related to shiploads or cargo bore a distinct economic character, since the focus remained on the commercial interests of the Dutch and all that may have influenced the activities of the trading companies in Asia. For example, newspapers reported on wars and conflict but often omitted human involvement: "This letter [of 1662] is said to report that from there 12 valiant warships were sent against the Chinese pirates, to counter them in the water. ${ }^{55}$ Political events were likewise of importance to trade and were similarly reported: 'Mekin, in China, the 28 December, 1674 . Here in this empire, it is full of unrest, and it seems great change is coming. 56

The economic character of Dutch-language news on China is further emphasised by dozens of advertisements announcing the sale of Chinese goods. These advertisements had become ubiquitous by the end of the century, and were intended (in the words of a contemporary):

For the sale or rent of dwellings, houses, fields, farms, gardens, cows, oxen, horses, sheep, books, \&c. prices of grain, bread, butter, cheese, meat, bacon and a hundred other things which concern general society or the communality, and which [messages] are especially useful and necessary

same year were interpreted as signs of Heaven's displeasure with the imprisonment of the Jesuit missionary. He was subsequently released. He died the next year.

52 Nieuhof, Het gezantschap, pp. 162-163; Keevak, Embassies to China, pp. 68-70.

53 Gottfried Wilhelm Leibniz, Sämtliche Schriften und Briefe (vol. 20, Berlin: Akademie Verlag), letter 318: Joachim Bouvet to Leibniz, pp. 533-534.

54 Florence Hsia, Sojourners in a strange land.Jesuits and their scientific mission in late imperial China (Chicago and London: The University of Chicago Press, 2009), pp. 110-111.

55 'Deze brief zegt men dat zoude behelsen dat 12 kloeke oorlog schepen van daar tegens den Chinese rovers waren gezonden, om hem te water tegen te gaan', in Ordinarisse middel-weeckse courante, 14 February 1662. See also Robert J. Anthony, 'Turbulent waters. Sea raiding in early modern South East China', The Mariner's Mirror, 99.1 (2013), pp. $23-38$, p. 27 .

56 'Mekin, in China, den 28 december, 1674 . Alhier in dit rijk is het vol beroerte, ende laat hem aanzien tot een grote verandering', in Oprechte Haerlemsche courant, 29 August 1675. See also Harry Miller, State versus gentry in early Qing dynasty China, 1644-1699 (New York: Palgrave Macmillan, 2016). 
for those who seek to engage in trade, and who wish to make an honest profit. ${ }^{57}$

Recently, Arthur der Weduwen has demonstrated that advertisements in Dutch newspapers changed from short announcements primarily about the sale of books to a broad range of goods and services. By the end of the century, these public notices of sale catered mostly to a local urban elite by providing 'new platforms for the exchange of commercial goods and luxuries'.58

In the Dutch Republic, advertisements were influenced and stimulated by the book trade. Until the 1640 , newspaper advertisements were generally dedicated to the sale of books and prints, through which booksellers targeted a broad public of potential buyers. During the first half of the century, devotional and spiritual works, recreational literature, professional and educational books, and maritime handbooks were most often advertised. ${ }^{59}$ This last category regularly included books on China. For example, in February 1645, the Amsterdam widow of Evert Cloppenburch offered a reprint of Jan Huygen van Linschoten's Itinerario for sale in Tijdinghe uyt verscheyde quartieren. ${ }^{60}$ By publicly announcing the sale of this expensive book, the widow hoped to catch the eye of the urban middle- and higher classes: those with the commercial, social, and political powers and means to be interested in such printed works. Advertisements for books in newspapers such as the Amsterdamse courant were not limited to books printed in Holland. In 1699, Jan van Leeuwen of Tiel in Guelders sold (through Anthony Schouten of Utrecht) his Reis-beschryvinge van Polen na Muscovien which contained 'some remarks on the journey of

57 For example:'ADVERTISSEMENTEN of BERIGTEN ... van Verkopingen, of Verhuuringen van Plaatzen, Huizen, Akkers, Hovingen, Tuinen, Koejen, Ossen, Paarden, Schapen, Boeken; \&c. Pryzen van Granen, Brood, Boter, Kaas, Vleisch, Spek, en 100 andere dingen meer die de algemeene Maatschappy of ' $t$ Zamenleving der Menschen betreffen, en welke Berigten inzonderheid nuttig en nodig zyn, voor Menschen die zig met de Kopenschap bemoejen, en daar door een eerlyke en geoorloofte winst zoeken', in J.H. Knoop, Kort onderwys, hoedanig men de couranten best lezen en gebruiken kan, Leeuwarden, Abraham Ferwerda, 1758, p. 16, via Arthur der Weduwen, 'From piety to profit. The development of newspaper advertising in the Dutch Golden Age', in S. Gøril Brandtzæg, Paul Goring and Christine Watson (eds.), Travelling chronicles. News and newspapers from the early modern period to the eighteenth century (Leiden and Boston, Brill, 2018), pp. 233-253, p. 233.

$5^{8}$ Der Weduwen, 'From piety to profit', p. 236.

59 Der Weduwen, 'From piety to profit', pp. $238-241$.

6o "t Amsterdam by de weduwe van Everhard Cloppenburch zal wort uitgegeven Ian Hugen van Linschoten, op nieu overzien en verbetert', in Tijdinghe uyt verscheyde quartieren, ${ }_{25}$ February 1645 . The book advertised is Jan Huygen van Linschoten, Reys-geschrift vande navigatien der Portugaloysers in Orienten (Amsterdam: Evert Cloppenburgh, 1644). 
Spatarus from Russia, by way of Siberia, to China'.61 Advertisements in newspapers enabled publishers to announce their books to the wealthy burghers of the republic, in and outside of the urban regions.

From the early 1640 on onwards, printed works were no longer the only advertised commodity in newspapers. Other products and goods were also offered for sale, indicating a shift not only in content of advertising but also in purpose. By promoting their Chinese wares in newspapers, merchants hoped to increase their profits and boost their overall business profile. ${ }^{62}$ Goods were often sold through a makelaar (broker). In September 1703, Cornelis de Roos de Jonge and Pieter Raket in the Amsterdamse courant offered the estate of the late Bartel Verhagen for sale, containing 'porcelain, lacquerware and many curiosities', among which ' 24 bottles of oriental figures of different sorts, six large pots, the same number of small ones, bottles, 1,00o "rinsing" bowls, a large batch of red, blue, and brown tableware for coffee, chocolate, and teacups, 100 teapots, a batch of large and small statues, a cabinet with nice shells and horns, Chinese bows, arrows, sables, and rudders with silver fittings', as well as 'unicorn horns, elephant teeth, and rhinoceros horns and much more. ${ }^{63}$ Likewise, in April 1685, Herman van Pamburg of Amsterdam announced a public auction to be held on 17 April of a batch of 'Chinese tea, various cotton goods, painted Chinese coverlets, Chinese flowers of gold and silk, three remarkable and large Chinese pots.' ${ }^{4}$ Throughout the century, the public of the Dutch

61 'Tot Tyel, by Jan van Leeuwen, Boekverkoper, is gedrukt, en te bekomen tot Utrecht by Antony Schouten, Reis-beschryvinge van Polen na Muscovien behelsende de Oorlogen van de Muscoviters in de Krim ... eenige aenmerkingen over de Reise van Spatarus van Ruschland doer Siberien, na China', in Amsterdamse courant, 6 June 1699.

62 Der Weduwen, 'From piety to profit', p. 424.

63 'Cornelis de Roos de Jonge, en Pieter Raket makelaers sullen op woensdag den 3 October 1703, ten huyse van Anthony Swanenburg, Kasteleyn in 't Oude Heere Logement, 's morgens ten 9 en 's namiddags ten 2 uuren verkoopen de nagelate porceleynen, lakwerk en veele rariteyten van Bartel Verhage, bestaende in 24 flessen Orientaelse figuuren van alderhande soort, 6 groote potten, kleynder dito, flessen, 1000 spoelkommen, een groote party root, blaeuw, en bruyn koffie, chokolaet, en teegoed, 10o de trekpotten, een party groote en kleyne beelden, een kabinet met mooiie schelpen, horens, \&c. Chineese Bogen, pylen, sabels, en roers met zilver beslag; eenhoorens, olifants-tanden, en rinoceros horens', in Amsterdamse courant, 15 September 1703.

64 'Herman van Pamburg, makelaar, zal dinsdag den 17 April 't Amsterdam verkopen een partij puike Chineese thee, diverse catoene lywaren, geschilderde Chineese spreien, gouden en zijde Chineese bloemen, 3 curieuze grote Chinese potten', in Oprechte Haerlemsche courant, 14 April 1685; Catalogus van de naargelaten porcelenen, lack-werck, en rariteyten ... naargelaten door Bartel Verhagen, die verkoft sullen worden ... den 3 october 1703. ten huyse van Anthony Swanenburg ... door de makelaars Cornelis de Roos de Jonge en Pieter Raket, s.l.s.n. [1703]; Notitie van de volgende porceleynen, lak-werk en rariteyten, nagelaten door Bartel Verhagen, die verkost sullen werden door de makelaars Cornelis de 
Republic indeed became very well informed about the sale of Chinese goods through newspaper advertisements, which also raised public visibility and familiarity with the Middle Kingdom.

China is also mentioned in newspaper advertisements as part of the somewhat unfortunate category of 'stolen goods'. These concerned personal announcements requesting the assistance of the general public. In the night of 15 February 1702, for instance, we learn that five dyed Chinese satins were stolen in Amsterdam, along with 'a very expensive veil with gold embroidered at both sides and heavy gold lace at the bottom; a very expensive apron, all made of gold; five dyed Chinese satins; a satin coverlet, as well as various women's clothing and many processed linens with the initials S.M.S. with a little crown above it'. The advertisement concludes with the hopeful request that if one sees the items somewhere, to 'please hold them, and bring them to Doctor Krytenberg, living at the Prinsegracht, near "The Elephant" brewery, for the reward of 25 guilders'. ${ }^{65}$ Doctor Krytenberg apparently believed the return of his textiles could be achieved through these means, for he posted the advertisement the day after the theft in the Amsterdamse courant as well as in the Oprechte Haerlemsche courant of 16 February. 66

Newspapers thus supplied readers in the Dutch Republic with ample opportunity to satisfy their interests in China in their own language. Yet, news coming from and pertaining to this country was limited and mostly concerned economic, political, or military affairs. The papers therefore primarily focused on information coming from the trading companies, since these reports had the greatest impact on the (economic) interests of Dutch readers. The bulk of references to China had less to do with the Middle Kingdom itself and more with the commercial products that were the direct result of the increased

Roos de Jonge en Pieter Raket ... den 3 october 1703. ten huyse van Anthony Swanenburg, s.l.s.n. [1703]; Appendix van eenig lackwerk ... stoffen en cabayen, behoorende tot de catalogus van de naargelaten porcelenen, lakwerk en rariteyten, naargelaten by Bartel Verhagen die verkost sullen werden den 4 october 1703. ten huyse van Anthony Swanenburg ... door de makelaars Cornelis de Roos de jonge, en Pieter Raket, s.l.s.n. [1703].

65 'Daar zyn tusschen Dingsdag en Woensdag den 15 February 1702 tot Amsterdam gestolen de navolgende goederen, een seer kostelyke Sluyer met gout aen weerzyde geborduurt, met een sware goude kant onder aen; een seer kostelyk voorschoot, alles van gout; 5 geverfde Chineese Satynen; een satyne gestikte Sprey; als mede verscheyde vrouwe klederen, en een partye gemaekte lynwaten, gemerkt s.M.s. en een kroontje daer boven. Die het bovengemelde of een van het eerte genoemde goed mogte voorkomen, gelieft het aen te houden, en te regt te brengen aen den Doctor Krytenberg, woont op de Prince-graft, by de Brouwery van de Oliphant, sal 25 gulden voor een vereering hebben', in Amsterdamse courant, 16 February 1702.

66 Oprechte Haerlemsche courant, 16 February 1702. 
contacts between Europe and Asia, such as books, commodities like tea and porcelain, and objects of art such as lacquerware. As such, newspapers reflected the economic impact of the increased intercultural contact between Europe and China for Dutch readers.

Dutch newspapers in French reported differently on China, which was mainly due to an expansion in readership. Their public consisted not only of French exiles in the Dutch Republic and readers in the Southern Netherlands and France, they also encompassed the whole European Republic of Letters as their potential audience. ${ }^{67}$ This broad circulation made news with a local (Dutch) economic focus superfluous, because Dutch readers of French papers were already supplied with economic news related to China in their own language. The majority of the reports on China in French-language newspapers concerned the Jesuits and their mission, especially since Louis XIV sent his own French envoy in the late 168os.

France came to play a more prominent role in the Chinese missionary effort during the last quarter of the seventeenth century. ${ }^{68}$ In the 1670 , the Flemish Jesuit Ferdinand Verbiest was instated as the new scientific teacher of the young Kangxi Emperor. Verbiest worried about the lack of Jesuit scientists, which he believed to be fundamental in the missionary efforts in China. He made an urgent appeal to the Jesuits in Europe, who then persuaded Louis XIV to send his own envoy. ${ }^{69}$ Known as the mathématiciens du roi (the 'king's mathematicians'), this envoy aimed at spreading French and Catholic influence at the Chinese court under the pretext of transmitting scientific knowledge. Sending a royally sponsored mission was also in line with Louis's policy of religious autonomy, which asserted the independence of the French Church from Rome. As related by Virgile Pinot, the main goal of the envoy combined interests of diplomacy, trade, and religion and its policies, with those of the sciences: 'Sending to China Jesuit mathematicians was but an expedient of the

\footnotetext{
67 Bots, De Republiek der Letteren, pp. 165-17o.

68 Louis Pfister states that Joachim Bouvet only presented '49 magnificently printed volumes' to Louis XIv. However, Bouvet himself declared in a letter to Gottfried Leibniz, on 18 October 1697, that he brought 300 volumes to the library of the French King. See L. Pfister, Notices biographiques et bibliographiques sur les jésuites de l'ancienne mission de Chine (1552-1773) (Shanghai: Imprimerie de la mission Catholique 1932), p. 434; Mungello, Curious land, p. 301.

69 Han Qi, 'Sino-French scientific relations', pp. 138-139.
} 
king's government in order to have in China missionaries who would not only be representatives of the Pope.70

The king's mathematicians were tasked with making astronomical observations, investigating native flora and fauna, and mastering various technical arts. ${ }^{71}$ In late 1684 and early 1685 , Joachim Bouvet, Jean de Fontaney, Jean-François Gerbillon, Guy Tachard, Claude de Visdelou, and Louis Le Comte were summoned to the Académie Royale des Sciences, where they met with Gian Domenico Cassini. Cassini was the director of the Observatoire de Paris, and he suggested that the Jesuits make astronomical observations in China. ${ }^{72}$ Cassini was primarily interested in Chinese chronology, biblical antiquity, and astronomical calculations (discussed in the previous chapter). As such, many of the Jesuits sent to China were respected astronomers, who brought with them a variety of their instruments. Their regular correspondence with the Académie Royale des Sciences in Paris made for a swift and broad distribution of the information gathered. ${ }^{73}$

70 Pinot, Documents inédits, p. 40; Lanrdy-Deron, 'Les mathématiciens envoyés en China par Louis XIV en 1685', pp. 425-429; Jami, The emperor's new mathematics, pp. 102-119.

71 Han Qi, 'Sino-French scientific relations through the French Jesuits and the Académie Royale de Sciences in the seventeenth and eighteenth centuries', in Stephen Uhalley and Xiaoxin Wu (eds.), China and Christianity. Burdened past, hopeful future (New York: M.E. Sharpe, 2001), pp. 137-147.

72 Cassini was also one of the founders of the Académie Royale des Sciences, and he had been interested in Chinese astronomy since at least 1689, when he received some manuscripts on this subject from the Duke du Maine (Louis-Auguste de Bourbon), Catherine Jami, 'The Jesuits' negotiation of science between France and China (1685-1722). Knowledge and modes of imperial expansion', in Laszlo Kontler etc., Negotiating knowledge in early modern empires. A decentered view (New York: Palgrave Macmillan, 2014), pp. 53-77.

73 The expansion of European religion and science in China had been greatly hindered during the 166os. During the early Qing period, an anti-Christian movement was launched by Yang Guangxian 楊光先, who was the head of the Bureau of Astronomy from 1665 to 1669 . It led, among other things, to the arrest of Jesuit missionary and imperial advisor Adam Schall von Bell, and the execution of a large number of Chinese converted astronomers. The events greatly influenced the young Kangxi Emperor, who soon began to study astronomy for himself in order to resolve a dispute concerning the calendar. Yang Guanxian was tasked to produce a valid calendar during a competition with the Jesuits astronomers, yet he could not do so. Yang was removed from his post as head of the Bureau of Astronomy, and replaced by the Flemish Jesuit Ferdinand Verbiest. The case against the Jesuits was subsequently reinvestigated, and all previous findings were reversed. See: Augustín Udías Vallina, Jesuit contribution to science. A history (Heidelberg: Springer, 2015), pp. 90-95; Stefano Salvia, 'The battle of the astronomers. Johann Adam Schall von Bell and Ferdinand Verbiest at the court of the celestial emperors', in Antoni M. Roca Rosell (ed.), The circulation of science and technology. Proceedings of the 4th international conference of the European Society for the History of Science (Barcelona: 
The French Jesuits arrived in Beijing in February 1688, and they were favourably received by the Qing Emperor Kangxi. The emperor appreciated them for their scientific knowledge, and he retained Gerbillion and Bouvet at court. ${ }^{74}$ The king's mathematicians regularly returned to Europe, where their informative manuscripts on their findings were soon turned into print. ${ }^{75}$ Regular contact between Paris and the Middle Kingdom facilitated the exchange of books, journals, instruments, and maps. This helped bring French and European science and culture to the Middle Kingdom and, in turn, further informed Europe about China. ${ }^{76}$

As the previous chapter demonstrated, the French reports on the Middle Kingdom came to overshadow information from other sources. ${ }^{77}$ During the last quarter of the seventeenth century, not only the printed medium containing information on China became increasingly French; via the royal mathematicians, the knowledge distributed in print began to focus on French sources and content as well. This contributed to a (partial) shift in production from the Dutch Republic to France. The Dutch Republic had been a favourite location for authors to publish their books on China throughout the seventeenth century. Even those affiliated with Rome or Paris often chose for the printing presses of Holland due to the high quality of their products, the excellent possibilities of distribution, and the relative lack of interference from government or church. ${ }^{78}$

However, in the last decade of the seventeenth century, those unique circumstances lost some of their decisive advantage. For one, governmental censure was less of an issue for the French Jesuits, as they worked and wrote

Institut d'Estudis Catalans, 2010), pp. 959-963; Mungello, The great encounter between China and the West, pp. 47-65.

74 Jami, The emperor's news mathematics, pp. 139-151.

75 Jean de Fontaney, Relation de ce qui s'est passé à la China en 1697, 1698 \& 1699, à l'occasion d'un établissement que M. l'Abbé de Lyonne a fait à Nien-Tcheou, Ville de la Province de Tche-Kiang (Liège: Daniel Moumal, 1700); Joachim Bouvet, L'estat present de la China, en figures (Paris: Pierre Giffart, 1697); Joachim Bouvet, Icones regia monarchae Sinarum nunc regnantis (Hannover, s.n., 1699); Jean-François Gerbillon and Philippe Couplet, Elementa linguae Tartaricae (Paris: Thomas Moette, [1682]); Louis Le Comte, Nouveaux mémoires sur l'etat présent de la China (Paris: Jean Anisson, 1696); Louis Le Comte, Des cérémonies de la Chine (Liège: Daniel Moumal, 1700); Guy Tachard, Voyage de Siam des pères Jesuites envoyez par le Roy aux Indes \& à la Chine (Paris: Arnould Seneuze and Daniel Horthemels, 1686).

76 Brockey, Journey to the East, pp. 126-163; Magone, 'Portugal and the Jesuit mission to China', pp. 3-30.

77 Ina Baghdiantz McCabe, Orientalism in early modern France. Eurasian trade exoticism and the ancient regime (Oxford and New York: Berg, 2008), pp. 101-136.

78 Dijstelberge, 'De cost en de baet', pp. 222-225. 
primarily in the service of their royal missionary policy. Besides, while the printers of Holland were especially renowned for their illustrated books in folio, the writings of the mathematicians were mostly published in relatively small sizes without engravings. Furthermore, for the proofreading and correcting of astronomical or mathematical works, someone versed in the specific field was preferred. While linguistic proofs could mostly be corrected by anyone knowledgeable in the text's language, the correctness of mathematical formulas proved difficult to gauge for someone without a firm grounding in the subject. This explains why the King's mathematicians chose printers and publishers in France, where they could control the production process; at least, for a while with little hinderance from the French government.

The production of books on China partially shifted from the Dutch Republic to France; yet, the Dutch still greatly influenced the image of the Middle Kingdom through the publication of newspapers, learned journals, and books. Dutch-made periodicals in French provided readers throughout the international Republic of Letters with information about the Middle Kingdom, the Jesuit mission and, eventually, the Chinese Rites Controversy. However, a distinct variance between reports related to China in French and Dutch papers soon became visible. Generally speaking, the Dutch papers focused inwards, led by the commercial and economic interests of their readers. They reported events that could impact the Dutch presence in Asia, paying special attention to incidents that might disrupt lines of trade and communication. A paper might, for instance, report on wars with these elements in mind: '[Letter] from Peking, capital of China, the 8th of October, 1696. During this year, the Emperor was busy undertaking war against the king of Elouth, a land located in Tartary, at three hundred leagues from here to the north-western side. ${ }^{79}$ In contrast, French-language papers were more outwardly focused, giving voice to those developments in, and relating to, China that could influence religious and cultural interactions in China. Additionally, French-language papers became preoccupied with the Chinese rites when these became part of a Jesuit-Jansenist controversy, in which Louis XIV tried to influence the mission in China through the Société des Missions étrangères de Paris and the Faculty of Theology of the Sorbonne.

The difference between French and Dutch-language newspapers is clearly evident when they report on the same event, illustrating how textual transmission (from source to printed paper) could influence content and interpretation. occupé] pendant cette année à faire la guerre au Roi d'Elouth, pays situé dans la Tartarie, à trois cent lieues d'ici du côté du Nord ouest', in Gazette de Rotterdam, 22 January 1699. 
On 3 March 1709, the Gazette d'Amsterdam informed its readers that 'this Thursday, the Pope offered his assistance to a congregation devoted to the mission in China, from which Father Provana, Jesuit, has arrived after a long and arduous journey, accompanied by a mandarin lodging with the Fathers of the Society [of Jesus]. ${ }^{\prime 0}$ On the same day, the Nouvelles extraordinaires des divers endroits carried the same notice but without mentioning the congregation on the China mission. ${ }^{81}$ The next day, the Oprechte Haerlemsche courant also reported on the arrival of Father Provana and the mandarin, using essentially the same words..$^{82}$ Three newspapers, two in French, and one in Dutch, noted the return of Father Provana: all reports were brief and in accordance with each other.

Yet a week later, only the Dutch Oprechte Haerlemsche courant carried another notice about Provana, this time specifying that 'the arrival of the Jesuit Provana with the Mandarin from the Empire of China has caused more than a little fear about these affairs at the court ... since it would do great damage to ... the commerce that would be lost in these regions' ${ }^{83}$ One week after the arrival of Antonio Provana, more information about his Asian stay was made public, and this knowledge posed a threat to commercial and religious interests of the Dutch. French-language papers would have had access to this information, if not by way of a primary source, then through other papers, yet they did not think it worthy enough for publication as their potential readers held fewer commercial stakes in the Middle Kingdom.

Publishing strategies were thus aimed at either French or Dutch potential readers and their presumed interests and demands. However, when the Chinese Rites Controversy became more publicly visible during the last decades of the seventeenth century, it overshadowed almost all other news related to China. As such, papers in both French and Dutch became increasingly preoccupied with this polemic debate.

8o 'Le Pape assista Jeudi à une Congrégation sur les Missions de la Chine; d'ou le Père Provana Jésuite est arrivé après une fort longue navigation, avec un Mandarin, qui est logé chez les Pères de la Société', in [Gazette d'Amsterdam], 22 March 1709.

81 'Le Jésuite Provana est revenu ici de la Chine, avec un Gentilhomme de ce Païs là', in Nouvelles extraordinaires de divers endroits, 22 March 1709.

82 This mandarin must have been Louis Fan Shouyi (1682-1753), a native of Shanxi province. Fan stayed in Europe for 12 years, primarily in Italy, before returning to China. 'Alhier is na en lange Reys uyt China aangekomen Pater Provuna, Jesuyt, met een mandarijn', in Oprechte Haerlemsche courant, 23 March 1709.

83 'De komste van den Jesuyt Provana met den Mandarijn uyt het Keyserrijck van China heeft geen kleyne vrees over de bewuste Saken aen dit Hof veroorsaeckt, ... aademael het een seer groot nadeel soude wesen voor ... de commercie die men in die Gewesten stont te verliezen', in Oprechte Haerlemsche courant, 3o March 1709. My emphasis. 
The debate concerning the Chinese rites had been an internal concern of religious authorities in Paris and Rome since the beginning of the seventeenth century. While the Jesuits claimed that the Chinese rites were secular rituals compatible with Christianity, Dominicans and Franciscans disagreed and reported the issue to Rome. In 1645, Rome's Sacred Congregation for the Propagation of the Faith, Sacra Congregatio de Propaganda Fide ('the congregation of the Roman Curia for missionary work and related activities'), sided with the latter and condemned the Chinese rites. However, in 1656, the Propaganda Fide briefly reversed this decision in favour of the Jesuits. In 1704, Rome issued a decree (later reinforced by a bull in 1715) in which Pope Clement XI banned the rites. Benedict XIV reaffirmed the prohibition and forbade further debate in 1742. In 1721, the Kangxi Emperor objected to the decrees of 1704 and 1715 and he banned Christian missions in China. The Yongzheng Emperor (1722-1735) also reinforced various anti-Christian policies during his reign. The Chinese Rites Controversy would not be formally resolved until 1939, when the Holy See allowed Christians to participate in ceremonies involving Confucius and to observe ancestral rites. In the meantime, leading universities in Europe had been involved in the conflict, together with eight popes and the Kangxi Emperor.

The sometimes-furious discussion often went beyond issues concerning the civil or religious character of Confucian ceremonies. In Rome, the Propaganda Fide had long wished to control the mission in Asia through its apostolic vicars. Since the Society of Jesus resisted such control, the Propaganda Fide had grown hostile towards them. This animosity was exacerbated by the fact that the Propaganda Fide was generally under the influence of the Dominican and Franciscan Orders. In France, the debate on the Chinese rites became part of a Jesuit-Jansenist controversy, combined with Louis XIV's efforts to influence the mission in China through the Société des Missions étrangères de Paris and the Faculty of Theology of the Sorbonne. ${ }^{84}$

Both Paris and Rome had motives that transcended the issues of the Chinese rites proper, which aggravated the discussion of the Jesuit policy of accommodation. However, this conversation was primarily carried out behind closed doors until 1696, when the publication of Nouveaux mémoires sur l'etat présent de la Chine by the mathématicien du roy Louis Le Comte catapulted the debate

84 Doyle, Jansenism; Tara Alberts, Conflict and conversion. Catholicism in Southeast Asia, 1500-1700 (Oxford: Oxford University Press, 2013), pp. 34-46. 
into the public consciousness. A veritable war of pamphlets broke loose, in which Dutch-made newspapers facilitated a swift distribution of the latest information and all its relevant movers and shakers. ${ }^{85}$

The Chinese Rites Controversy was a long-contested issue, which became an increasingly public debate from the late 1600 onwards. The periodic press subsequently picked up the dispute, which also increased the number of reports on China in both Dutch and French newspapers. Before the issue of the Chinese rites entered the European stage, Dutch-made newspapers in French had been quite confident in their evaluation of the Jesuit mission. This may be related to the fact that news from China in French-language papers was largely supplied by the Society of Jesus, especially through letters sent by their missionaries to Rome or Paris. The Gazette de Rotterdam of 12 September 1695 printed one such missive, reporting that the Chinese emperor was very fond of the Christian religion and the Society of Jesus: 'From Rome a letter was sent to Father de la Chaise. It had been written on the 1oth of February 1694 in Beijing, the capital of China, by father Antoine Thomas, Flemish missionary to the general of the Jesuits. This letter reports that the emperor is always very affectionate towards the Christian religion and the Society of Jesus. ${ }^{86}$ It may be clear from such reports that the Jesuit provenance heavily influenced both tone and content, presenting the results of the mission as inherently positive. Dutch-language newspapers were apparently influenced by this Jesuit approach as they, too, added a subtle note of confidence to the mission, albeit in a more implicit manner: 'That the emperor of China has deigned the missionaries by means of an edict, to preach the gospel in his empire, and to his subjects to embrace the Christian religion' ${ }^{87}$

85 Jacques Davy, 'La condemnation en Sorbonne des "Nouveaux memoires sur la Chine" de P. Le Comte', Recherches de science religieuse, 37 (1950), pp. 366-397.

86 'On a envoié de Rome au Père de la Chaise une lettre écrite de Peking Capitale de la Chine le 1o. Février 1694 par le Père Antoine Thomas missionnaire Flamand [sic] au Général des Jésuites. Cette lettre porte que l'Empereur est toujours très-affectionné à la Religion Chrétienne \& à la Compagnie de Jesus', in Gazette de Rotterdam, 12 September 1695. Antoine Thomas came from Namur in Wallonia and as such was not Flemish. Until 1692, the city was part of the Spanish Netherlands, after which it was annexed to France by Louis XIV.

87 'Dat de keizer van China door een edict aen de Missionarissen vergunt heeft, het Euangelium in sijn Rijck te verkondigen, en aen sijn Onderdanen, de Christelijcke religie t'omhelsen', in Oprechte Haerlemsche courant, 27 April 1697. This notice may refer to Kangxi's edict of Christianity, issued in 1692. This decree compared Christianity on an equal level with Confucianism: 'The Europeans are very quiet; they do not excite any disturbances in the provinces, they do no harm to anyone, they commit no crimes, and their doctrine has nothing in common with that of the false sects in the empire, nor has it any tendency to excite sedition. We decide therefore that all temples dedicated to the 
During the last years of the seventeenth century, French-language newspapers began to demonstrate a certain opposition to the Jesuit presence in China, especially where it concerned the issues of Confucius and the Chinese rites: 'The Jesuits understand that they can no longer prevent, nor elude for long, an evaluation of the case of the Chinese cults ... themselves having remained quietly in agreement about the truth of the facts concerning the rites of Confucius and [worship of] the dead, which are the principal points to evaluate. 88 Another paper demonstrates concerns about the role of Pope Innocent XIII (1691-1700), who by the end of 1699 was already gravely ill: 'One does not know whether or not the setback of the Pope's illness will postpone the judgment of the case of the Chinese rites against the Jesuits.' ${ }^{89}$ Meanwhile, papers in Dutch kept printing news about China in a more descriptive manner. Yet, the main sources of news shifted from shipping reports to letters from missionaries, which were combined with tidings from Rome. These also began to inform readers about the growing unease of the Roman Curia concerning the role of the Jesuits in China.

The Rites Controversy came to a boiling point on 18 October 1700, when eight deputies filed their report on Louis Le Comte's Nouveaux mémoires sur l'état présent de la Chine to the Faculty of Theology at Sorbonne University of Paris, to decide whether this account should be officially censured. After brief deliberations, the faculty strongly condemned the text, denouncing the majority of 19 selected passages as 'false, reckless, scandalous, impious, contrary to the word of God, heretical, subversive to the faith and religion of Christ, obviating the virtues of the Passion and the Cross of Jesus Christ. ${ }^{\prime 0}$ The main reason for this censure was Le Comte's defence of the Jesuit accommodation

Lord of heaven, in whatever place they may be found, ought to be preserved, and that it may be permitted to all who wish to worship this God to enter these temples, offer him incense, and perform the ceremonies practised according to ancient custom by the Christians. Therefore let no one henceforth offer them any opposition.' See Pelican history of the Church. History of Christian missions (vol. 6, Harmondsworth: Penguin Books, 1964), pp. 189-19o.

88 'Les Jésuites s' aperçoivent qu'ils ne peuvent plus empêcher ni reculer long-tem[p]s le jugement de la cause des cultes Chinois ... eux-mêmes étant demeurez tacitement d'accord de la vérité des faits touchant les cultes de Confucius \& des morts, qui sont les principaux points à juger', in Gazette d'Amsterdam, 19 November 1699.

89 'On ne sait pas si le contretemps de la maladie du Pape éloignera le jugement de la cause des cultes Chinois contre les Jésuites', in [Gazette d'Amsterdam], 3o November 1699.

90 'Fausse, téméraire, scandaleuse, impie, contraire à la parole de Dieu, hérétique, renversant la foi et la religion chrétienne, rendant inutile la vertu de la Passion et de la Croix de Jésus-Christ', in Roger Étiembles, Les Jésuites en Chine. La querelle des Rites, 1552-1773 (Paris: Julliard, 1966), pp. 56-57. 


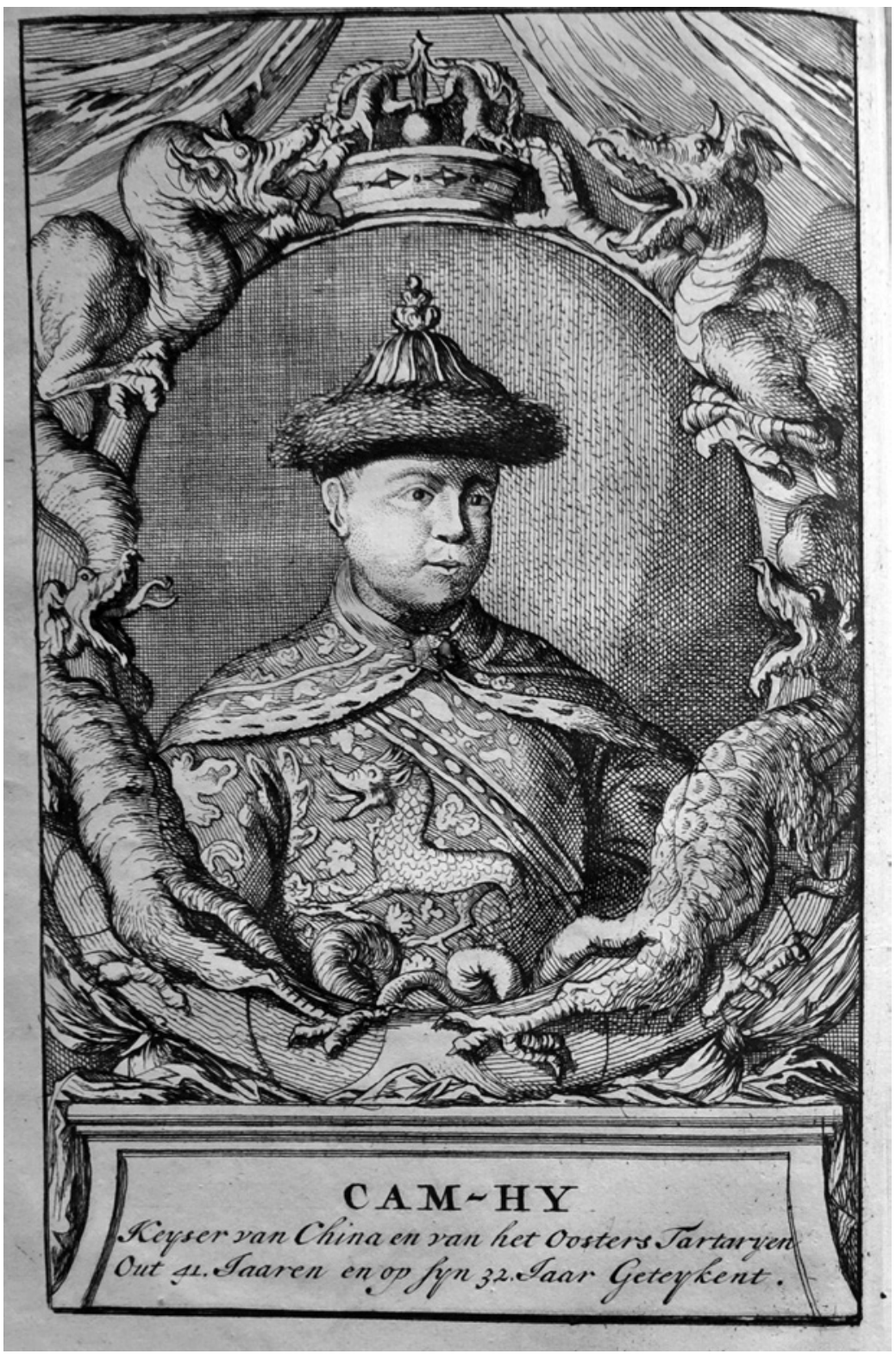

FIGURE 28 Portrait of the Kangxi emperor in Louis Le Comte, Beschryvinge van het machtig keyserryk China (The Hague: Engelbreg Boucquet, 1698) Allard Pierson Amsterdam (O 87-21) 
of various Chinese rites, which were considered idolatrous by the Société des Missions étrangères de Paris. ${ }^{91}$ Anti-Jesuit forces celebrated the censure as a victory, especially so, because it was soon followed by additional official attacks on the Jesuit interpretation of the Chinese rites. These assaults proved so effective that Rome eventually ruled against Jesuit accommodation in the Papal bulls Ex illa die (1715), and Ex quo singulari (1742). ${ }^{92}$

Le Comte had been part of the French envoy sent to China to strengthen Louis XIV's influence in the Middle Kingdom. ${ }^{93}$ After a stay of only two years, Le Comte was enjoined to return to Europe to inform his superiors of the dire situation in which the Jesuits in China had found themselves. He left in 1691 and reported to Rome and Paris. Thereafter, he returned to France, where he became confessor to the duchess of Bordeaux, never to return to China again. ${ }^{94}$ In France, Le Comte soon started work on a book about China, entitled Nouveaux mémoires sur l'état présent de la Chine, which was first published by Jean Anisson in Paris. Two reprints appeared within the year, and translations in English, Dutch, and German followed before the end of the century.

The work was mainly descriptive with a focus on 'the largest provinces, and many cities, palaces, rivers, canals, ships, roads, and passages, as well as its [China's] antiquity, good statesmanship and government. ${ }^{95}$ Had Le Comte constrained himself to a simple description of China, the book would probably

$91 \quad$ Isabelle Landry-Deron, 'Confucius au coeur des polémiques sur la scène européenne au tournant des XVII e et XVIII ${ }^{\mathrm{e}}$ siècles', in Flora Blanchon (ed.), Le nouvel âge de Confucius. Modern confucianism in China and South Korea (Paris: Pups, 2007), pp.155-163, pp.157-159.

92 Mungello, Curious land, pp. 356-358. For the full text of both edicts see Dun Jen Li, China in transition, 1517-1911 (New York: Van Nostrand Reinhold, 1969), p. 224.

93 Pfister, Notices biographiques et bibliographiques sur les Jésuites de l'ancienne mission de Chine, pp. 440-441.

94 John W. Witek, Controversial ideas in China and Europe. A biography of Jean-François Foucquet, S.J. (1665-1741) (Rome: Institutum Historicum S.I. 1982), p. 68.

95 Subtitle to the Dutch edition: Behelsende d'overgroote Provintien, en menigvuldige Steden, Paleysen, Rivieren, Kanalen, Schepen, Wegen, en Passagien,.... Wyders Der selver Outheyt, goede Staatkunde, Regeringe, in Le Comte, Beschryvinge Van het machtige Keyserryk China, title page. The English translation also mentions 'Memoirs and observations topographical, physical, mathematical, mechanical, natural, civil, and ecclesiastica', as well as 'the Chinese pottery and varnishing; the silk and other manufactures; the pearl fishing; the history of plants and animals. Description of their cities and publick works; number of people, their language, manners and commerce; their habits, economy, and government', in Louis Le Comte, Memoirs and observations topographical, physical, mathematical, mechanical, natural, civil, and ecclesiastical, title page. The German subtitle specifies that the book concerns: 'Durch Curieuse An verschiedene/ hohe Geist- und weltliche Standes-Personen/Staats-Ministren/ und andere vornehme gelährte Leute gefertigte Send-Schreiben/Den Liebhabern seltener Sachen zu sonderbarer Vergnügung vorgestellet, in Le Comte, Das heutige Sina, title page. 
not have caused such a stir as it did. The book's biggest issue lay in the second main subject, on 'the progress of the conversion of the inhabitant to the Christian faith. ${ }^{96}$ The popular success of this propagandistic account made the book a convenient target for those trying to undermine the Jesuit mission, and its rather unsophisticated explanation of complex theological issues only added fuel to the fire.

David Mungello has noted that it is both surprising and unfortunate that Le Comte became such a primary figure in the Chinese Rites Controversy; his short stay in China had prepared him poorly for the role of spokesman for Jesuit accommodation. ${ }^{97}$ To begin, it is unlikely that he was literate in Chinese or had any real acquaintance with Chinese literature. Besides, his writings were 'far less intellectually distinguished', compared to those by his fellow mathematicians. ${ }^{98}$ However, while Visdelou may have been better versed in Sinology, Bouvet more creative, and Fontaney and Gerbillon more scientifically educated, Le Comte's popular tone and subject made his work attractive to a much larger public of potential readers. His Nouveaux mémoires concentrated on descriptions of travel, climate, and geography, as well as shorter treatments of Chinese government, history, culture, language, religion, and the Jesuit mission.

These were exactly the subjects that, time and again, had proved their popular potential. It comes as no surprise, therefore, that Le Comte was the only one of the king's mathematicians to be translated and reprinted. ${ }^{99} \mathrm{On} 2$ February 1697, Oprechte Haerlemsche courant announced the publication of the Dutch translation, printed and published by Engelbrecht Boucquet in The Hague, 'with fine illustrations.' 100 Earlier that year, a French edition was published by Étienne Roger and Jean Louis de Lorne in Amsterdam. ${ }^{101}$ The work was

96 'En eyndelijk De voortgangen van de bekeringe der Inwoonders tot het Christen Geloof', in Le Comte, Beschyvinge van het machtige Keyserryk China, title page.

97 Mungello, Curious land, pp. 330-331.

98 Mungello, Curious land, pp. 330-331.

99 At least ten reprints had been published, and an English translation was made in 1697 by Benjamin Tooke and Sam Buckley of London, while the Dutch translation appeared in The Hague in 1698. In 1699-1700, a German reprint was made by Christoph Riegel and Christoph Fleischer of Frankfurt.

100 'In 's Gravenhage by Engelbrecht Boucquet is gedruckt en wert uytgegeven: Nieuw Verhael van den tegenwoordigen Staet van China door den Vader Louys Le Comte, Jesuyt, Mathematicus van den koning van Vranckrijck, in 4: met schoone figuren', in Oprechte Haerlemsche courant, 2 February 1697; Louis Le Comte, Beschryvinge van het machtige keyserryk China (The Hague: Engelbrecht Boucquet, 1697).

101 Louis Le Comte, Nouveaux memoires sur l'etat présent de la Chine (Amsterdam: Etienne Roger and Jean louis de Lorme, 1697). 


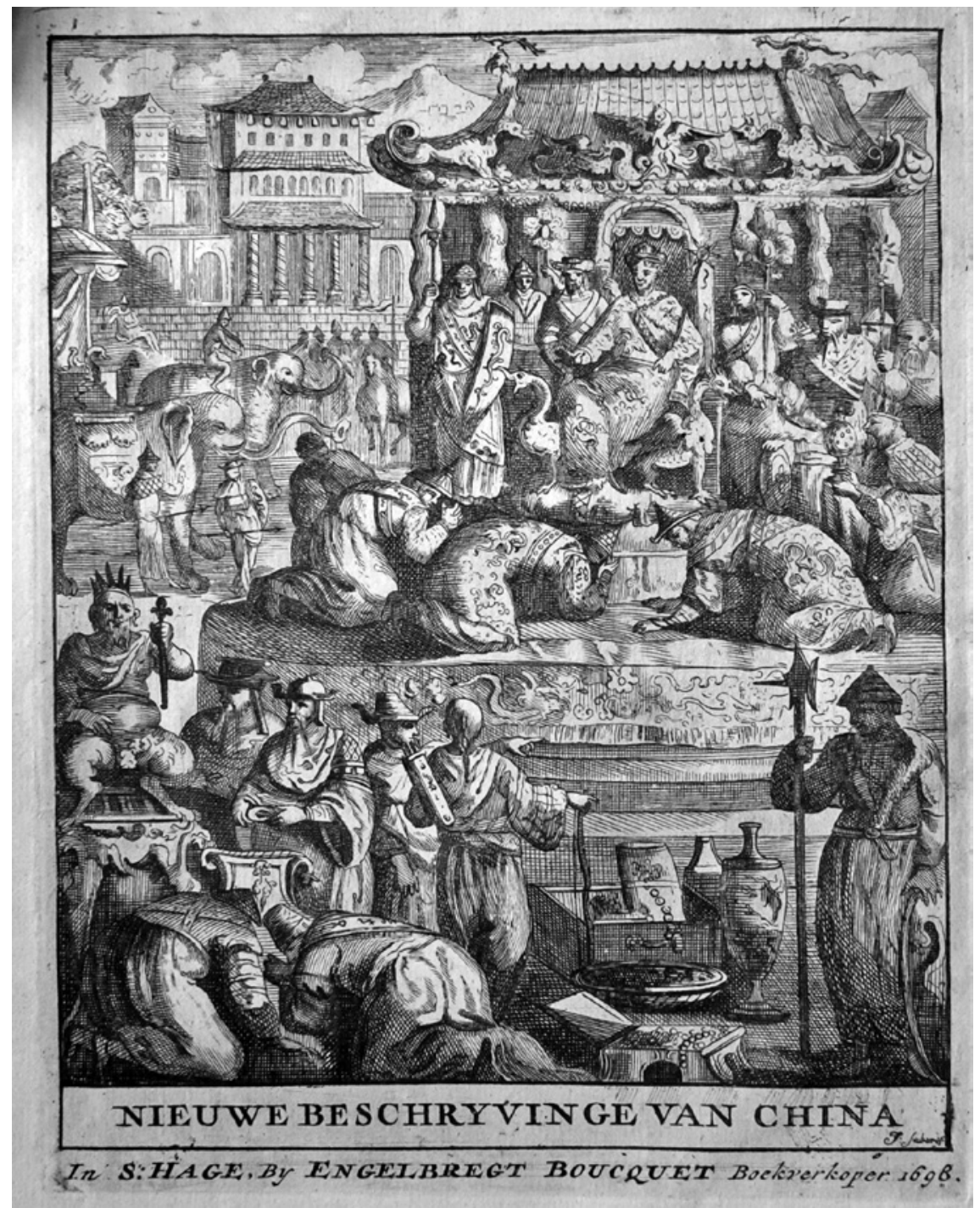

FIGURE 29 Louis Le Comte, Beschryvinge van het machtig keyserryk China (The Hague: Engelbreg Boucquet, 1698) Allard Pierson Amsterdam (O 87-21) 
apparently so much in demand that Antoine Schelte of Amsterdam had already issued a reprint of the French edition in $1698 .{ }^{102}$ Through the popularity and broad dissemination of Nouveaux mémoires, and its subsequent discussion in the periodic press, Louis Le Comte would become one of the prime figures in 'that phase of the Chinese Rites Controversy which climaxed at Paris in $1700^{\prime}{ }^{103}$

Sorbonne's censure of Le Comte not only exacerbated the institutional discussion of the Chinese Rites Controversy, it also made the dispute over the religiosity of Confucius's teachings and other Chinese rituals visible to the general public through the pamphlet war of 1700 . One of the most vicious of these was L'enterrement de Confucius, a leaflet distributed in various churches in France. ${ }^{104}$ It attacked both Confucius and the Jesuits: 'Confucius lived in error and died in paganism. His ashes enclosed in an urn awaited in horror for the reunion with his soul, to be sad companions to his eternal misery: but he still he found the geniuses who, against their own conscience and by cruel stubbornness, have resurrected him in order to present him as a model for Christianity.'105

The growing public dissemination of the Rites Controversy was not limited to France. The forceful rejection of Confucius in L'enterrement was reprinted verbatim in the Dutch-made newspaper Gazette de Rotterdam less than a month later, on 4 November 1700 . According to the editor of the Gazette, readers would surely be interested since 'the case of Father Le Comte had caused

102 Louis Le Comte, Nouveaux memoires sur l'etat présent de la Chine (Amsterdam: Antoine Schelte and Henri Desbordes, 1698).

103 Mungello, Curious land, p. 33 .

104 Landry-Deron, 'Confucius au coeur des polémiques', p. 158. For a fairly complete list of pamphlets, see R. Streit, Bibliotheca missionum (30 vol., Freiburg: Herder, 1917-2012), vol. 7, pp. 1-44. The most important publications include: [Louis Thiberge, Lettre ... au Pape, sur les idolatries et les superstitions chinoises (Brussels, 1700); Réflexions générales sur la lettre qui paraît sous le nom de messieurs des missions étrangères au pape, touchant les cérémonies chinoises (Paris, 1700); Affaire de la Chine (Paris, 1700), which included the pamphlets: Louis Le Comte, Lettre à monseigneur le duc de Mayne sur les cérémonies de la Chine. Lettre écrite de la province de Fokien, dans la Chine, où l'on rapporte le cruel traitement que les chrétiens des Jesuites ont fait souffrir à Maigrot et au R.P. Croquet; Histoire apologétique de la conduite des Jésuites en Chine adresée a MM. des Missions Etrangères (s.l, 1700).

105 'Confucius avait vécu dans l'erreur et étais mors dans la paganisme. Ses cendres resserrées dans une urne attendaient avec horreur la réunion de son âme, pour être les tristes compagnes de son malheur éternel: et cependant il a trouvé des génies, qui contre leur propre conscience et par un entêtement cruel l'avaient ressuscité et proposer pour modèle aux Chrestienne', in Gazette de Rotterdam, 4 November 1700. 
so much turmoil.'106 The Dutch-made periodical Mercure historique et politique printed a similar notice, here accompanied by the comment that "if he [Le Comte] does not defend it better ... he should ... stop digging in the ashes [of Confucius]': 107

Le Comte shared the role of spokesman for the Jesuit policy of accommodation with Charles Le Gobien, a French Jesuit and procurator in Paris for the China mission who had never travelled to the Middle Kingdom. However, apropos the public discussion of the Chinese rites, Le Gobien had written extensively on the country. ${ }^{108} \operatorname{In} 1698$, he joined Le Comte with the publication of Historie de l'edit de la Chine en faveur de la religion Chrestienne. He allied himself to Le Comte by providing an account and explanation of the Kangxi Emperor's Edict of Toleration 正教奉傳 (1692), which recognised the Roman Catholic Church, barred attacks on Catholic churches, and legalised the practice of Christianity in China. ${ }^{109}$ To this, Le Gobien added a clarification of the honours presented by the Chinese to Confucius, followed by letters and reports of events related to the Chinese Rites Controversy. Due to the combined efforts of Le Comte and Le Gobien, the polemics in France soon reached 'an almost hysterical pitch', which would last from 1697 until 1700, when a final decision on the subject was made by Pope Clement XI. ${ }^{110}$

In France, the offensive against the Chinese rites was led by the eminent Dominican theologian Noël Alexandre. ${ }^{111}$ In 1699, he published a lengthy exposition on the history of the Dominican Order in China and their growing discontent with the Jesuit policy of accommodation. ${ }^{112}$ The following year,

106 'L'affaire du Père Le Comte a tant fait de bruit', in Gazette de Rotterdam, 4 November 1700.

107 'Mais s'il ne le défend pas mieux ... qu'il ne fouille plus dans ses [Confucius] cendres', Mercure historique et politique (November 1700), p. 534.

108 Lach and Van Kley, Asia in the making of Europe, p. 429.

109 Ku Weiying, 'Father Tomás Pereira, SJ, the Kangxi Emperor and the court Westerners', in Artur K. Wardega and Antonio Vasconcelos de Saldanha (eds.), In the light and shadow of an emperor. Tomás Pereira, SJ (1645-1708) (Newcastle upon Tyne: Cambridge Scholars Publishing, 2012), pp. 64-84; Nicolas Standaert, "The "Edict of tolerance". A textual history and reading, in Wardega and Vasconcelos de Saldanha (eds.), Tomás Pereira, SJ, pp. 308-358.

110 Lach and Van Kley, Asia in the making of Europe, p. 429.

111 Ulrich L. Lehner, The Catholic Enlightenment. The forgotten history of a global movement (Oxford: Oxford University Press, 2016).

112 Noël Alexandre, Apologie des dominicains, missionnaires de la Chine ou Réponse au livre du père Le Tellier, jésuite, intitulé. Défense des nouveaux chrétiens et a l'éclaircissement du P. Le Gobien, de la même compagnie, sur les honneurs que les Chinois rendent à Confucius et aux morts (Cologne: Corneille d'Egmond, 1699). The work was ostensibly printed in Cologne, yet in reality was published in Amsterdam, see E. Weller, Die falschen und fingierten Druckorte. Repertorium der seit Erfinding der Buchdruckerkunst unter falscher Firma 
Alexandre issued Conformité des cérémonies chinoises avec l'idolatrie Grecque et Romaine, which was a direct attack upon the Jesuit position by way of a comparison between these rites and the (already) acknowledged idolatrous ceremonies of ancient Greeks and Romans. ${ }^{113}$ Again in 1700, the Dominican launched his last major salvo by publicly addressing seven letters to Le Comte concerning the rites, together with the publication of a collection of writings about Confucian ceremonies. ${ }^{114}$ Much of the flurry of publications that accompanied and fuelled the public discussion of the controversy was supposedly published in Cologne, either by Corneille d'Egmond or Jean le Sincere. However, this Cologne imprint is likely fictitious. ${ }^{115}$ It is more reasonable to suspect that the pamphlets were published in Amsterdam. ${ }^{116}$

Neither the political nor ecclesiastical powers of the Dutch Republic were ever able (or willing) to exercise the same degree of control over the production and trade in print as France or England could. ${ }^{117}$ While decrees and proclamations were made by the States General or the provincial States against the publication of certain texts on a regular basis, even works that were deemed seditious, blasphemous, or otherwise harmful to the state, church, or public interest could usually be published without much difficulty. ${ }^{118}$ The publication

erschienenen deutschen, lateinischen und französischen Schriften (3 vol., Leipzig: Wilhelm Engelmann, 1856-1864).

113 Noël Alexandre, Conformité des cérémonies chinoises avec l'idolatrie Grecque et Romaine. Pour servir de confirmation à l'apologie des Dominicains missionaires de la Chine (Cologne: Corneille d'Egmond, 1700). Again, this work was supposedly published in Cologne, yet in reality came from Amsterdam, see Weller, Die falschen und fingierten Druckorte Repertorium.

114 Noël Alexandre, Lettre d'un docteur de l'ordre de S. Dominique sur les cérémonies de la Chine ([Amsterdam]: s.l.s.n., 1700), see Weller, Die falschen und fingierte Druckorte Repertorium; Recueil des pièces des differens messieurs des missions Etrangères et des religieux de l'ordre de S. Dominique, touchant le culte qu'on rend à la Chine au philosophe Confucius (Cologne: Jean le Sincere, 170o); For a listing see n. 4. in Foster Stockwell, Westerners in China. A history of exploration and trade, ancient times through the present (Jefferson and London: McFarland \& Company, 2017), p. $5^{\circ}$.

115 Begheyn, Jesuit books in the Dutch Republic, p. 419.

116 E. Weller, Die maskirte Literatur der älteren und neureren Sprachen (vol. 2, Leipzig: Falcke \& Rössler, 1856), pp. 63-65.

117 Femke Deen, David Onnekink, and Michel Reinders (eds.), 'Pamphlets and politics. Introduction', in Femke Deen, David Onnekink, and Michel Reinders, Pamphlets and politics in the Dutch Republic (Leiden and Boston: Brill, 2010), pp. 3-30; Roelof Harms, 'Thievery of literature. Consequences of the interaction between politics and commerce for the form and content of pamphlets', in Deen, Onnekink, and Reinders, Pamphlets and politics in the Dutch Republic (Leiden and Boston: Brill, 2010), pp. 37-62.

118 Roelof Harms, 'Handel in letteren. De ambulante handel in actueel drukwerk in zeventiende-eeuws Amsterdam', De Zeventiende Eeuw, 23 (2007), pp. 216-229. 
of pamphlets concerning the Chinese rites served a dual purpose: first, it was a relatively easy way to keep the printing presses going and, thus, make money. A pamphlet could be made within a day, distributed the next, and be profitable within the week. Second and related to the first, pamphlets fuelled the discussion on Chinese rites, which led to the publication and sale of additional pamphlets (and maybe even increased demand for related work).

For instance, in 1700 alone, nine pamphlets in 12 editions by Noël Alexandre were issued in Amsterdam. ${ }^{119}$ His seven Lettres d'un docteur en theologie de l'ordre de S. Dominique sur l'idolatrie et les superstitions de la Chine demonstrate the 'back and forth' of the debate between supporters and detractors of the Chinese rites, which saw their publishers laughing all the way to the bank. Charges and rebuttals of the rites circulated in the form of 'letters' to the Pope. and other dignitaries of the Catholic Church. The Jesuits were accused of insincerity, idolatry, and a lack of uniformity in their ideas. Alexandre further argued that, while the Jesuits reconciled the Chinese god as the creator of the universe with the law of nature and the Ten Commandments, they had concealed Original sin, the faith in Jesus Christ and His incarnation, death and resurrection because they felt it to be irrelevant. ${ }^{120}$

With these pamphlets, Dutch book producers took yet another publication strategy. Pamphlets allowed for discussion on a widespread level, and they served to change the manner in which religious, cultural, and social conversations were viewed and carried out. As such, pamphlets also created new ways of communication and news styles of language. Before this point, the country had seemed a static entity in the eyes of the European public. Through the Chinese rites pamphlet war, the Middle Kingdom had now truly become

119 Noël Alexandre, Conformité des ceremonies chinoises avec l'idolâtrie Grecque et Romaine (s.n. [Amsterdam], 1700); Apologie des dominicains missionnaires de la Chine. Ov Response au livre du père Le Tellier jésuite, intitulé, Défense des nouveaux chrétiens (s.n. [Amsterdam], 170o); VII. lettre d'un docteur en théologie de l'ordre de S. Dominique. Sur l'idolâtrie et les superstitions de la Chine (s.n. [Amsterdam], 170o); VI. lettre d'un docteur en théologie de l'ordre de S. Dominique, sur l'idolâtrie \& les superstitions de la Chine (s.n. [Amsterdam], 170o); $V$. lettre d'un docteur en théologie de l'ordre de Saint Dominique sur l'idolâtrie et les superstitions de la Chine (s.n. [Amsterdam], 170o); IV.(-V.) lettre d'un docteur en théologie de l'ordre de Saint Dominique sur l'idolâtrie et les superstitions de la Chine (s.n. [Amsterdam], 1700); III. lettre d'un docteur de l'ordre de Dominique au R.P. Le Comte ... sur son système de l'ancienne religion de la Chine (s.n. [Amsterdam], 170o); Lettre d'un docteur de l'ordre de S. Dominique sur les ceremonies de la Chine au R.P. Le Comte (s.n. [Amsterdam], 170o); Conformitá delle cerimonie chinesi, colla idolatria greca, e romana (s.n. [Amsterdam], 1700); Conformité des cérémonies chinoises avec l'idolâtrie grecque et romaine (s.n. [Amsterdam], 1700).

Alexandre, III. Lettre, p. 4 f. 
a subject of public discussion and polemic debate. ${ }^{121}$ These urgent events related to China added historical dimension 'in the background and individual personalities or discrete events in the foreground'. ${ }^{122}$

Noël Alexandre brought the case against the Jesuits officially to the Sorbonne in 1700, assisted by Nicolas Charmot of the mission étrangères. ${ }^{123}$ A letter dated 20 April 1700 from the foreign mission of Paris to Pope Innocent XIII denounced six propositions taken from both Le Comte and Le Gobien's works. Another letter followed on 1 July, written by Solomon Prious, Doctor of theology at the Sorbonne and one of the directors of the mission, condemning Le Comte's Nouveaux mémoires, Le Gobien's Historie, and the anonymous Lettre sur les ceremonies de la Chine, on the basis that they contained propositions that had to be censored. On 2 August, Charles Boileau, member of the deputies, presented the report of the foreign mission to the Sorbonne Faculty of Theology. Subsequently, the faculty began their deliberations on the subject on 17 August.

By this time, Louis Le Comte had become a well-known figure and representative of the Jesuit mission, and his presence as such can be traced through newspapers and periodicals. Both French and Dutch papers reported on his comings and goings, like his departure from France and arrival in Rome in July 1700 , and the rumour that he would soon return to China. ${ }^{124}$ Notices in French-language papers on Le Comte and his fellow Jesuits turned grim after Nouveaux mémoires was brought before the Sorbonne in 1700. At the end of that month, just before the book was condemned, the Nouvelles extraordinaires des divers endroits somewhat prematurely reported that 'the king [Louis XIV] has proposed three Jesuits to the duchess of Burgundy, so that she may choose one as her confessor, in place of Father Le Comte who is disgraced'.125 In August, 'this affair continues in a heated manner' for Le Comte. ${ }^{126}$ On the 26 th of that

\footnotetext{
121 Harline, Pamphlets, printing, and political culture in the early Dutch Republic, p. 3.

122 Van Kley, 'News from China', p. 562.

123 In Historia cultus Sinensium seu varia scripta de cultibus Sinarum, inter vicarios apostolicis gallos aliosque missionarios, \& patres Societatis Jesu controversis, oblata Innocentio XII. Pontifici Maximi. I-II, Charmot edited a collection of evidence which concerned the case against the Jesuits. See Streit VII, pp. 23-24. Again, this work was probably printed in the Netherlands, while the title page states it was published in Cologne, see Weller, Die falschen und finfierten Druckorte Repertorium.

124 Oprechte Haerlemsche courant, 17 July 1700; [Gazette d'Amsterdam ], 19 July 1700; Gazette de Rotterdam, 19 July 1700.

125 'Le roy a proposé a la Duchesse de Bourgogne 3 Jésuites, afin qu'Elle en choisisse un person Confesseur en la place du Père Le Comte qui est disgracié', in Nouvelles extraordinaires de divers endroits, 20 July 1700 (my emphasis).

126 'Cette affaire poursuit avec chaleur', in [Gazette d'Amsterdam], 26 August 1700.
} 
same month, a French paper reported that the Faculty of Theology gave their opinion on the propositions, and that they had declared them 'reckless [and] scandalous.' ${ }^{27}$ Three other French-language newspapers copied this message in the days that followed.

Surprisingly, while papers in French presented the censure of Le Comte's propositions as a done deal, Dutch-language papers were more nuanced. They spoke of the 'supposed idolatry of Confucius', giving Le Comte the opportunity to 'refute the allegations of the missionaries of China on the false idolatry of Confucius', which (at least according to Oprechte Haerlemsche courant) he did so with 'very great expertise.'128 However, it would take another two months before a Dutch newspaper would again comment on the proceedings of the Sorbonne, while French papers remained very clear in their opposition of the Jesuits.

The deliberations of the Sorbonne concluded on 18 October, when the propositions of Le Comte and Le Gobien were condemned as 'false, erroneous and foolhardy'.129 La Gazette d'Amsterdam articulated why Confucius and the Jesuit accommodation of the Chinese rites were denounced and Le Comte's book served as a concrete example of everything that was wrong with the Jesuit mission in China. In this tiding, a writer who signed with the pseudonym 'De Champ Veille' ['From the Vigilant Field'] first repeated the propositions of Le Comte, and then emphasised their absolute 'falseness, recklessness, scandalousness and wrongness.' ${ }^{130}$ The author finished his litany by noting that the 'the sacred faculty further declares that it will not hear of approving the other things contained within these books.'131

Dutch newspapers provided lessinformation about the censure of LeComte's book than their French counterparts. Only one Dutch digest, Europische mercurius, reported in detail on the issue; however, it mainly outlined the arguments from the side of the Jesuits. This news digest devoted two pages in its second edition of 1700 (July to December) to the 'Assembly of the Faculty of

127 'Téméraites, scandaleuse', in [Gazette d'Amsterdam], 26 August 1700.

128 'De gesupposeerde Idolatrie van Confucius', in Oprechte Haerlemsche courant, 4 September 1700 (my emphasis); 'dat den Jesuyt Le Comte met seer groote bescheydentheydt sijne wederleggingen tegen de Beschuldigingen van de Missionarissen van China over de valsse idolatrie van Confucius in 't Licht gegeven heeft', in Oprechte Haerlemsche courant, 2 October 1700.

129 Étiemble, Les Jésuites en Chine, pp. 56-57.

130 'fausse, téméraire, scandaleuse \& erronée', in [Gazette d'Amsterdam], 28 October 1700.

131 'La Sacrée Faculté déclare en outre qu'elle n'entend pas approuver les autres choses contenues dans ces Livres', in [Gazette d'Amsterdam], 28 October 1700. 
Theology of Paris about the case of the Chinese rites.'132 It opened with a short description of the proceedings of the Sorbonne and their decision to censure Le Comte. The digest seemingly presented both sides of the argument but with the effect of nuancing the severity of the case: 'Among the doctors who gave their opinion, were some who thought the word heresy to be too grave.'133

In a salient move, Louis Le Comte's propositions were quoted in full; however, without the disclaimer that these were considered idolatrous by the Sorbonne. This information was, of course, available to the editors of this digest, since other Dutch newspapers had already included it in their reports. In Europische mercurius, Dutch readers were thus confronted with statements like 'China has practised the purest precepts of moral philosophy, while Europe and almost all the rest of the world lay in error and corruption', but without the context to put the recently condemned nature of this proposition into perspective. ${ }^{134}$ For a fuller understanding of this article, readers could have obtained this context from other sources, such as articles in French-language newspapers. Yet, so far, no report in a Dutch-language publication elaborated on the fact that the statements in Le Comte's work had been condemned by the Sorbonne.

The Europische mercurius was not yet finished with the case. In the first issue of 1701, a notice entitled, 'Jesuits protest against the verdict of the Sorbonne', listed all the arguments given by the Jesuits as to why the censure was unjust. ${ }^{135}$ The popularity of Le Comte's book was emphasised: 'Over the past four years ... his books have been reprinted several times, even in various languages'. Moreover, in those years 'neither complaints nor allegations were made.' ${ }^{136}$ Besides, Le Comte would have based his work 'only on historical facts about religion in the ancient Chinese books', and works written by members of the Sorbonne. ${ }^{137}$ It is therefore proper that 'Father Le Comte protests [in order]

132 'Vergadering van de Faculteit der Theologie van Parys over de zaak van den Dienst der Chineezen', in Europische mercurius, March 1701, pp. 139-141.

133 'Onder de doctoren, welke opineerden, waren eenigen die meenden dat het woord Kettersch al te hard was', in Europische mercurius, March 1701, pp. 139-141.

134 'China heeft de zuiverste grondregelen van de Zedekonst geoeffend, terwyl Europa, en byna al het overige van de Wereld, in dwaling en verdorvenheid lag', in Europische mercurius, March 1701, pp. 139-141.

135 Europische mercurius, January 1701, pp. 99-101.

136 'Dat sedert vier Jaren ... dezelve verscheide maalen zyn herdrukt, zelfs in verscheidene taalen', 'geene Klagten of beschuldigingen zyn opgesteld geweest', in Europische mercurius, January 1701, pp. 99-101.

137 'Puur als Historische feiten op het geloof der oude Chineesche Boeken', in Europische mercurius, January 1701, pp. 99-101. 
to nullify all that has been undertaken so far. ${ }^{138} \mathrm{~A}$ protest which, according to the Europsiche mercurius, should be considered seriously.

However, this was not to be. The Sorbonne and Pope Clement XI remained firm in their condemnation of the propositions, along with a general rejection of the accommodation of the Chinese rites by the Jesuit missionaries in China. On 20 November 1704, Pope Clement XI condemned all the rites and rituals with the decree Cum Deus optimus, which also outlawed any further discussion. The Papal bull Ex illa die of 19 March 1715 reaffirmed this condemnation and, in 1742, Benedict XIV reiterated Clement XI's decrees, which required all missionaries in China to take an oath never to argue the matter again. ${ }^{139}$

As a direct result of the Pope's objections to the Chinese rites, the attitude in China towards Catholic missionaries changed. In 1721, the Kangxi Emperor commented that: 'I have concluded that the Westerners are petty indeed. It is impossible to reason with them.... From now on, Westerners should not be allowed to preach in China, to avoid further trouble..140 The Jesuits were especially affected in the following years. Despite all their efforts, their progress in China stalled and their movements were severely restricted. Newspapers reported that 'the emperor of China published a rigorous edict against all missionaries ... who have to leave the empire on punishment of death' ${ }^{141}$ But, as the Oprechte Haerlemsche courant informed its readers, matters could always

138 'Vader Le Comte protesteert van nulliteit van alles't geen tot hier toe is ondernomen', in Europische mercurius, January 1701, p. 101. The arguments were probably taken from Louis Le Comte's Éclaircissement sur la dénonciation faite au Pape des Nouveaux mémoires de la Chine ([s.l.], 1700).

139 Confirmatio et innovatio constitutionis incipientis. Ex illa die (Rome: Ex typograhia Reverendae Camerae Apostolicae, 1742); George Minamiki, The Chinese Rites Controversy. From its beginning to modern times (Chicago: Loyola University Press, 1985), p. 69.

140 Li, China in transition, p. 22.

141 'De Keyser van China had een rigoreus Edict tegen al de Missionarissen ... die op Levensstraf uyt het Rijck moeten gaen, laten publiceren', in Oprechte Haerlemsche courant, 7 December 1709. Oprechte Haerlemsche courant was not entirely correct here. The expulsion of all missionaries and the prohibition of Christianity only took place in 1724, decreed in January of that year by Kangxi's son, the Yonzheng Emperor. The 'rigorous edict' the Haarlem newspaper speaks of probably refers to a permit needed by all missionaries in which they had to declare to adhere to the rules of Matteo Ricci, which were in favour of an accommodation of the Chinese rites. Additionally, while the newspaper reported that the missionaries had to leave on punishment of death, many missionaries asked for a permit, and those that did not were expelled or went to Macao. See Thomas David DuBois, Religion and the making of modern East Asia (Cambridge: Cambridge University Press, 2011), pp. 92-92. 
be worse: 'We have heard that many of these missionaries embarked on a ship to save their lives, but have lost them by shipwreck'.142

This chapter aimed to explain how Dutch-made newspapers and digests reported on China during the last quarter of the seventeenth century, and how the Dutch provenance of printed works influenced possible representations of the Middle Kingdom. Dutch tolerance, combined with the country's famous economic pragmatism, allowed printers, publishers, and editors to publish periodicals. The quality of the Dutch product guaranteed that even Catholic authors would often choose Amsterdam over Rome or Paris. Add to this the extensive trading network of Dutch book producers, it becomes clear that the Dutch Republic had long been Europe's primary storehouse for publications on the Middle Kingdom, in which the veritable 'Dutch-ness' of the product only added to their appeal.

In this period, Dutch printers and publishers provided much of Europe with periodic printed works, not only in Dutch but in French, English, Spanish, Italian, and Yiddish. The papers in French catered to the international Republic of Letters and the growing number of readers literate in French. Dutch-made newspapers enjoyed a considerable readership and they were dispersed far and wide. They were read not only by professionals but by an increasing number of literate citizens from a middling background. On the pages of newspapers and digests, which summarised and supplemented news that was heard elsewhere, these readers were informed about events happening across Europe and the world beyond.

This growing number of newspapers reports significantly changed the manner in which China was represented. Before their introduction, notices about the Middle Kingdom had been rather static descriptions of an idealised and remote empire. However, the increase of more detailed information replaced these descriptions (at least partially) with more dynamic images. The introduction of news reports also expanded the possibilities for discussion and debate: Chinese events began to provoke public speculation and polemic argument. Here, the cultural and religious background of the reporting parties determined how the news was presented and interpreted.

Newspapers from the Dutch Republic frequently reported on China, informing readers about events happening in the Middle Kingdom: especially those developments that would have an impact on Europe. However, there was a distinct divergence between reports in Dutch and French. Dutch news mainly

142 'En men verstaet, dat veele van dese Missionarissen, op een schip gegaen zijnde, om 't leven te behouden, door Schipbreuck 't selve verloren hebben', in Oprechte Haerlemsche courant, 7 December 1709 . 
focused on those events that might affect the economic interests of the United Provinces, such as the fates of ships and wars and conflicts that could disrupt lines of trade and commerce. Additionally, numerous advertisements for products from China accentuated this primarily economic focus of Dutch news on the Middle Kingdom. As such, most news was less concerned with China itself and more with the commerce that resulted from the contacts between China and Europe.

In contrast, papers in French had a far broader potential audience, the whole Republic of Letters, making economically centred reports redundant. Frenchlanguage reports were more concerned with the Jesuits and their mission. In the late 168 os, Louis XIV sent a French Jesuit mission to China, which came to play an increasingly influential role in providing Europe with knowledge of the Middle Kingdom. Regular contacts between Paris and Beijing facilitated the exchange of goods and information, which not only helped to bring French and European science and culture to China, but also further informed Europe about the Middle Kingdom.

Dutch publishing strategies thus aimed at French or Dutch readers and their presumed wishes and demands. Yet, in the last decades of the seventeenth century, the Chinese Rites Controversy cast a long shadow over all other news related to China, turning the country into a dynamic and interactive entity. The debate had long been an internal concern of religious authorities in Rome and Paris. However, Le Comte's Nouveaux mémoires of 1696 catapulted the debate over the religiosity of Confucius's teachings and other Chinese rituals onto the public stage. In this context, the resulting pamphlet war was fundamental in disseminating the latest information in a swift and comprehensive manner.

The official censure of Le Comte's book in 1700 further exacerbated the public discussion of China. And thanks to the increasing number of books, pamphlets, newspapers, and digests, the dispute was brought to the public's attention. This growing public dissemination was not limited to the Catholic regions of Europe, Dutch newspapers also concerned themselves with the issue. For the Dutch, their interests remained economic rather than religious. The controversy provided an easy way to keep the printing presses going and periodicals made a quick profit. The debate on Chinese rites also fuelled further discussion, leading to additional publications and maybe even increase demand for related works.

It is necessary to note that when regarding newspapers, periodicals, and pamphlets, the function of the printing location plays an important role as well. In the analysis of the development and distribution of early modern periodicals on China, it becomes evident that even publications that seem far removed from the Dutch printing phenomenon do, in fact, owe much to 
the unique influence of the culture of print of the Dutch Republic in the seventeenth century. Through newspapers, news digests, learned journals, pamphlets and other periodical printed works, Dutch printers, publishers, and booksellers facilitated the public discussion of various religious, political and cultural matters: the Chinese Rites Controversy among them. Their publishing strategies allowed for conversation on a broad and influential level. As a result, they changed the way in which China and its religion and philosophy was viewed and represented. Indeed, the extensive coverage of the Chinese Rites Controversy in Dutch-made periodicals made the Middle Kingdom truly a subject of public discussion, dissemination, and polemic debate.

Readers who, beforehand, may have had only a pedestrian knowledge of China were now urged to seek out newsworthy information in the periodic press. They did so for a variety of reasons, and representations of China during the last decades of the seventeenth century were as much the result of developments back home as they were due to events in the Middle Kingdom itself. Newspaper reports thus confirm the degree to which China had been integrated into early modern Dutch culture. We have seen that the periodic press, learned journals and newspapers alike, demonstrates how the Middle Kingdom became increasingly assimilated into the main currents of society during the final decades of the seventeenth century. However, this assimilation soon narrowed the gaze of spectators and players alike; China may have provided the stage, the players remained decidedly European. 